\title{
Suppressor of Hairless directly activates transcription of Enhancer of split Complex genes in response to Notch receptor activity
}

\author{
Adina M. Bailey and James W. Posakony ${ }^{1}$ \\ Department of Biology and Center for Molecular Genetics, University of California San Diego, La Jolla, California \\ 92093-0366 USA
}

We have investigated the functional relationships among three loci that are required for multiple alternative cell fate decisions during adult peripheral neurogenesis in Drosophila: $\operatorname{Notch}(N)$, which encodes a transmembrane receptor protein, Suppressor of Hairless $[\mathrm{Su}(\mathrm{H})]$, which encodes a DNA-binding transcription factor, and the Enhancer of split gene complex [E(spl)-C], which includes seven transcription units that encode basic helix-loop-helix (bHLH) repressor proteins. We describe several lines of evidence establishing that $\mathrm{Su}(\mathrm{H})$ directly activates transcription of $\mathrm{E}(\mathrm{spl})-\mathrm{C}$ genes in response to $\mathrm{N}$ receptor activity. Expression of an activated form of the $\mathbf{N}$ receptor leads to elevated and ectopic $\mathrm{E}(\mathrm{spl})-\mathrm{C}$ transcript accumulation and promoter activity in imaginal dises. We show that the proximal upstream regions of three $\mathrm{E}(\mathrm{spl})-\mathrm{C}$ genes contain multiple specific binding sites for $\mathrm{Su}(\mathrm{H})$. The integrity of these sites, as well as $\mathrm{Su}(\mathrm{H})$ gene activity, are required not only for normal levels of expression of $\mathrm{E}(\mathrm{spl})$ - $\mathrm{C}$ genes in imaginal disc proneural clusters, but also for their transcriptional response to hyperactivity of the $\mathrm{N}$ receptor. Our results establish $\mathrm{Su}(\mathrm{H})$ as a direct regulatory link between $\mathrm{N}$ receptor activity and the expression of $\mathrm{E}(\mathrm{spl})-\mathrm{C}$ genes, extending the known linear structure of the $N$ cell-cell signaling pathway.

[Key Words: Drosophila; neurogenesis; peripheral nervous system; transcriptional activation; signal transduction]

Received July 31, 1995; revised version accepted September 8, 1995.

Cell-cell interaction plays a major role in conditional cell fate specification, and hence cell type diversification, during the development of multicellular organisms. Significant advances are currently being made toward elucidating the molecular mechanisms by which an intercellular communication event occurring at the cell surface can ultimately influence the state of gene expression in a cell, which in turn helps define the cell's differentiative fate. In particular, there is intense recent interest in the responses of transcriptional regulators to the activity of cell surface receptors.

The peripheral nervous system (PNS) of the Drosophila adult includes a large number of mechanosensory bristles, distributed in a characteristic pattern over the body surface. The four component cells of each of these multicellular sensilla-a neuron and three non-neuronal accessory cells-derive, by a stereotypic lineage, from a single progenitor cell, the sensory organ precursor (SOP) (Hartenstein and Posakony 1989). Cell-cell interactions play an essential role in the determination of the SOP

${ }^{1}$ Corresponding author. cell fate. During the late larval and early pupal stages, small groups of cells within the imaginal discs and histoblast nests (undifferentiated epithelia that will give rise to the cuticular structures of the adult) begin to express the proneural genes achaete $(a c)$ and scute $(s c)(\mathrm{Cu}-$ bas et al. 1991; Skeath and Carroll 1991). The basic helix-loop-helix (bHLH) proteins encoded by these genes function, probably in hetero-oligomeric complexes with the ubiquitously expressed proneural bHLH protein daughterless (da) (Cronmiller and Cummings 1993), as transcriptional activators to confer on the "proneural cluster" cells the competence to adopt the SOP fate $/ \mathrm{Ca}$ brera and Alonso 1991; Cubas et al. 1991; Skeath and Carroll 1991; Van Doren et al. 1991, 1992; Singson et al. 1994). However, within each proneural cluster this potential ultimately becomes restricted so that only a single cell is stably determined as an SOP. The refinement of proneural clusters to single SOP cells depends on inhibitory cell-cell interactions mediated by the neurogenic group of genes, which includes Notch $(N)$, Delta (DI), Suppressor of Hairless [Su(H)], and the Enhancer of split gene complex [E(spl)-C]. Loss-of-function mutations in any of these loci cause the commitment of supernu- 
merary proneural cluster cells to the SOP fate (Dietrich and Campos-Ortega 1984; Hartenstein and Posakony 1990; Simpson 1990; Schweisguth and Posakony 1992; Parks and Muskavitch 1993; Tata and Hartley 1995).

The lineage by which the SOP cell generates the four component cells of the bristle consists of three successive asymmetric cell divisions (Hartenstein and Posakony 1989; Posakony 1994). Cell-cell interactions dependent on the neurogenic genes again play an essential role in cell fate specification in this lineage (Dietrich and Campos-Ortega 1984; Hartenstein and Posakony 1990; Parks and Muskavitch 1993; Schweisguth and Posakony 1994; Tata and Hartley 1995). These interactions ensure that at each division the daughter cells adopt distinct fates (Posakony 1994).

A substantial body of evidence indicates that the products of certain of the neurogenic genes are members of a signal transduction pathway. Both genetic and biochemical data lead to the conclusion that the transmembrane proteins encoded by $N$ and $D l$ function as a receptor and a ligand, respectively, in the cell-cell interactions described above (Fehon et al. 1990; Heitzler and Simpson 1991; Struhl et al. 1993|. Recently, in vitro biochemical and cell culture experiments have implicated the $\mathrm{Su}(\mathrm{H})$ protein as a transducer of a $\mathrm{N}$-mediated signal (Fortini and Artavanis-Tsakonas 1994), consistent with the cellautonomous action of the $\mathrm{Su}(H)$ gene (Schweisguth 1995). $\mathrm{Su}(\mathrm{H})$ associates directly with the ankyrin repeats in the intracellular domain of the $\mathrm{N}$ receptor; activation of the receptor by interaction with the Dl ligand leads $\mathrm{Su}(\mathrm{H})$ to translocate to the nucleus (Fortini and Artavanis-Tsakonas 1994). Su(H), like its mammalian homologs, is a sequence-specific DNA-binding protein that activates transcription in transient transfection assays through sites containing the core sequence GTGGGAA (Brou et al. 1994; Grossman et al. 1994; Henkel et al. 1994; Tun et al. 1994).

The E/spl)-C includes seven transcription units that encode bHLH repressor proteins (Delidakis and Artavanis-Tsakonas 1992; Knust et al. 1992), as well as several other genes, including groucho (grol, which encodes a nuclear protein of the WD-40 family (Hartley et al. 1988; Delidakis et al. 1991) that interacts directly with the $\mathrm{E}(\mathrm{spl})-\mathrm{C}$ bHLH proteins and appears to function as a corepressor (Paroush et al. 1994); and $E(s p l) \mathrm{m} 4$, which encodes a small protein of unknown function (Klämbt et al. 1989). Several of the $\mathrm{E}$ (spl)-C bHLH genes, in addition to $E(s p l) m 4$, are expressed specifically in the proneural clusters of the wing imaginal disc under the direct control of the proneural transcriptional activators (Singson et al. 1994). Genetic experiments have been interpreted to indicate that the products of the $\mathrm{E} / \mathrm{spl} \mid-\mathrm{C}$ act in the proneural cluster to effect the $\mathrm{N}$-mediated signal (Vässin et al. 1985; de la Concha et al. 1988; Lieber et al. 1993), and Jennings et al. (1994) have shown recently that the accumulation of $\mathrm{E} / \mathrm{spl} / \mathrm{-C}$ bHLH proteins in the embryonic neuroectoderm is positively regulated by $\mathrm{N}$ receptor activity.

Both in SOP specification and in cell fate determination in the bristle lineage, the Hairless $(H)$ gene exhibits loss- and gain-of-function phenotypes that are the opposite of those of the neurogenic genes (Bang et al. 1991; Bang and Posakony 1992; Posakony 1994; Schweisguth and Posakony 1994). For example, the SOP cell fails to be determined stably in the proneural clusters of $H$ null mutants (Bang et al. 1991; Bang et al. 1995), whereas hyperactivity of $H$ leads to the commitment of additional cells in each proneural cluster to the SOP fate (Bang and Posakony 1992). Moreover, loss-of-function mutations in $\mathrm{Su}(\mathrm{H})$ (Schweisguth and Posakony 1994) and the E(spl)-C (Bang et al. 1995) are at least partially epistatic to $H$ null alleles. Thus, $H$ behaves genetically as a negative regulator of neurogenic gene activity (Vässin et al. 1985), and appears to promote commitment to the SOP and other cell fates by making cells resistant to $\mathrm{N}$-mediated inhibitory signaling (Bang and Posakony 1992; Posakony 1994). Recently, Brou et al. (1994) have presented in vitro evidence that the $\mathrm{H}$ protein associates directly with $\mathrm{Su}(\mathrm{H})$ and inhibits its DNA binding and transcriptional activation functions.

In this report we describe several lines of evidence establishing that $\mathrm{Su}(\mathrm{H})$ directly activates transcription of $\mathrm{E}(\mathrm{spl})-\mathrm{C}$ genes in reponse to $\mathrm{N}$ receptor activity. We show that expression of an activated form of the $\mathrm{N}$ receptor leads to elevated and ectopic E(spl)-C transcript accumulation and promoter activity in imaginal discs. We have identified multiple specific binding sites for $\mathrm{Su}(\mathrm{H})$ in the proximal upstream regions of three $\mathrm{E}(\mathrm{spl})-\mathrm{C}$ genes, and find that in each gene two of these sites are arranged in a novel, evolutionarily conserved, inverted repeat configuration. We demonstrate that intact $\mathrm{Su}(\mathrm{H})-$ binding sites, as well as $\mathrm{Su}(\mathrm{H})$ gene activity, are required not only for the normal levels of expression of E(spl)-C genes in proneural territories, but also for their transcriptional response to hyperactivity of the $\mathrm{N}$ receptor. Finally, we show that $H$ is an effective in vivo inhibitor of $\mathrm{N}$-induced, $\mathrm{Su}(\mathrm{H})$-mediated activation of $\mathrm{E}(\mathrm{spl})-\mathrm{C}$ promoters. Our results establish $\mathrm{Su}(\mathrm{H})$ as a direct regulatory link between the activity of the $\mathrm{N}$ receptor and the expression of $\mathrm{E} / \mathrm{spl} \mid-\mathrm{C}$ genes in the proneural clusters of the wing imaginal disc, extending the known linear structure of the $N$ cell-cell signaling pathway in this system.

\section{Results}

Transcription of E(spl)-C genes is regulated positively in imaginal discs by the activity of the $N$ receptor

To investigate the relationship between the activity of the $N$ signaling pathway and the expression of $\mathrm{E}(\mathrm{spl})-\mathrm{C}$ genes in imaginal tissue, we made use of a mutant $N$ gene, Notch(intra), expressed under the control of the inducible hsp70 promoter (Struhl et al. 1993). Notch(intra) encodes only the $\mathrm{N}$ intracellular domain, a ligandindependent, constitutively active form of the $\mathrm{N}$ receptor. Using in situ hybridization, we examined the effect of Notch(intra) expression on the accumulation of transcripts from the $m 4$ transcription unit of the E(spl)-C ¡Klämbt et al. 1989). In the wild-type wing imaginal disc, $E(s p l) m 4$ RNA appears specifically in a proneural cluster 
pattern (Singson et al. 1994) (Fig. 1A). We find that hyperactivity of the $\mathrm{N}$ receptor not only causes elevated levels of $E(\mathrm{spl}) \mathrm{m} 4$ transcript accumulation within the proneural clusters but ectopic accumulation as well (Fig. 1B).

We then investigated whether the positive effect of $N$ pathway activity on $E(s p l) m 4$ transcript accumulation has a transcriptional basis. We constructed an $E(s p l) m 4$ promoter-reporter fusion gene in which a 510-bp fragment of the proximal promoter region $(-502$ through +8 ) (Klämbt et al. 1989; Singson et al. 1994) drives expression of the Escherichia coli lacZ gene. This construct directs a pattern of reporter gene activity that recapitulates the proneural cluster pattern of endogenous $E$ (spl)m4 transcript accumulation (Fig. 1C). We found that induction of the hsp70-Notch(intra) transgene causes both an expansion of the normal territories of $m 4-1 a c Z$ expression and broad ectopic expression (Fig. 1D). Thus, the effect of Notch(intra) expression on the activity of the $E(\mathrm{spl}) \mathrm{m} 4$ promoter mimics its effect on transcript accumulation from the endogenous $E(s p l) m 4$ gene. We conclude that transcription of $E(s p l) m 4$ in the wing imaginal disc can be regulated positively by $\mathrm{N}$ receptor activity.

To evaluate whether this regulatory relationship extends to other members of the $\mathrm{E}(\mathrm{spl})-\mathrm{C}$, we made use of an $E(s p l) m 8$ reporter gene $\left[\mathrm{P}\left[\mathrm{w}^{+}, m 8-2.61\right]\right.$ (Kramatschek and Campos-Ortega 1994)]. In this construct, a 2.6-kb DNA fragment extending upstream of $E(\mathrm{spl}) \mathrm{m} 8$ $[E(s p l) m 7+551$ through $E(s p l) m 8+123]$ directs lac $Z$ expression in a pattern that resembles the normal pattern of $E(s p l) m 8$ transcript accumulation in the wing disc (Fig. 1E) (Hinz et al. 1994; Singson et al. 1994). When Notch(intra) is expressed, broad ectopic activity of this m8-lacZ reporter is observed (Fig. 1F). Thus, the promoters of two structurally unrelated genes of the E(spl)-C are individually responsive to the activity of the $N$ signaling pathway in imaginal discs.

The proximal upstream regions of $E$ (spl)-C genes contain specific binding sites for the $\mathrm{Su}(H)$ protein

Insight into the possible biochemical link between $\mathrm{N}$ receptor activity and transcription of $\mathrm{E} / \mathrm{spl})-\mathrm{C}$ genes was provided by the identification of multiple $\mathrm{Su}(\mathrm{H})$ binding site consensus sequences (Henkel et al. 1994; Tun et al. 1994 ) in the proximal upstream regions of three $\mathrm{E}$ (spl)-C genes. Figure $2 \mathrm{~A}$ shows that $E(s p l) m 4, E(s p l) m 8$, and $E(s p l) m \gamma$ have, respectively, three, three, and four putative $\mathrm{Su}(\mathrm{H})$ binding sites within several hundred base pairs upstream of their transcription start sites. These 10 sites define a relatively constrained consensus sequence in which the 7-nucleotide "core" site, GTG ${ }^{\mathrm{G}} /{ }_{\mathrm{A}} \mathrm{GAA}$, is invariably flanked on the 5 ' side by a pyrimidine and by A or C on the $3^{\prime}$ side (Fig. 2A).

Using the electrophoretic mobility-shift assay (EMSA), we tested the ability of the $\mathrm{Su}(\mathrm{H})$ protein, expressed in $E$. coli as a fusion with glutathione $S$-transferase (GST) (Guan and Dixon 1991), to bind these sites in vitro. Fig-
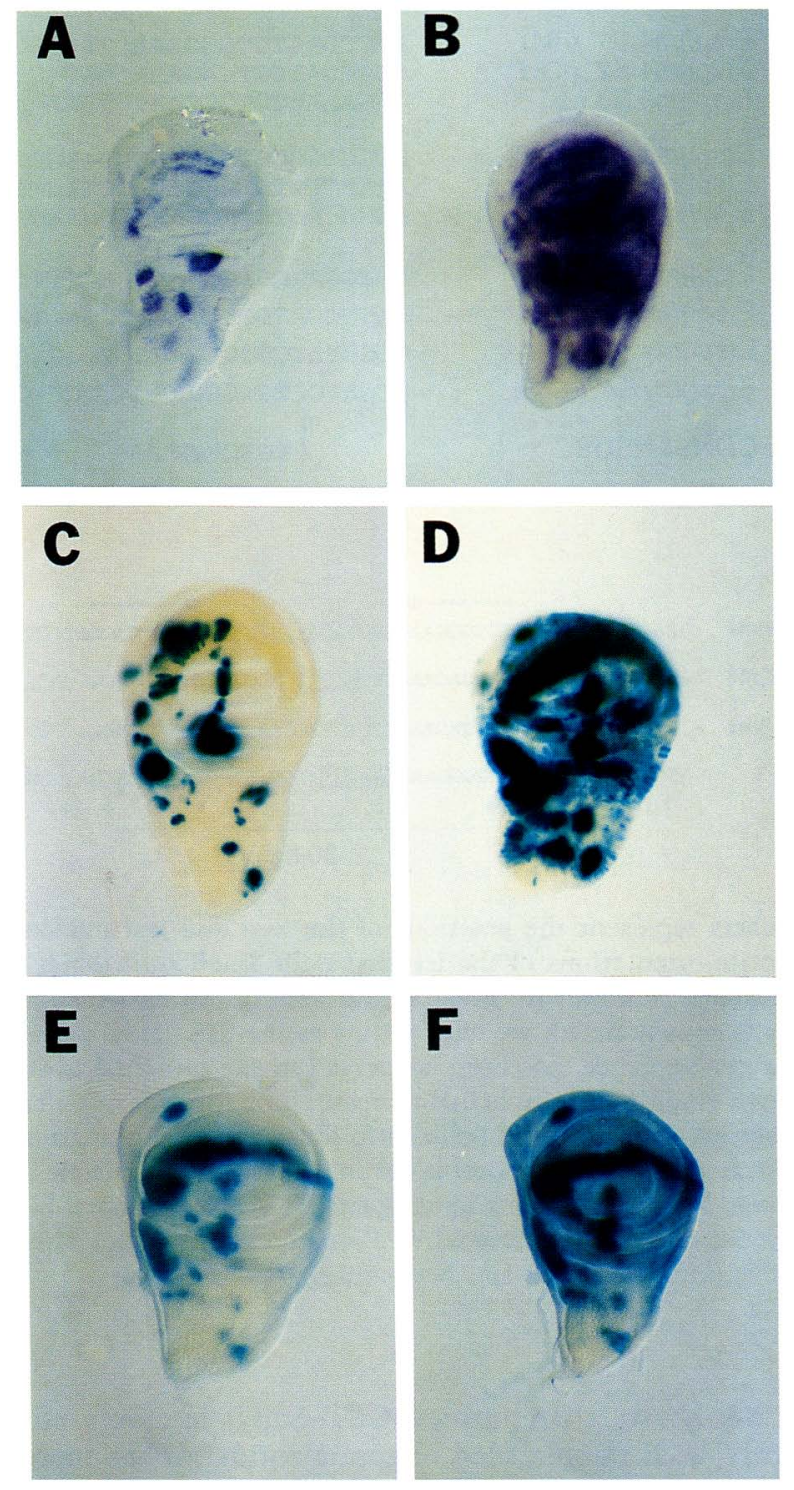

Figure 1. Expression of an activated form of the $\mathrm{N}$ receptor leads to elevated and ectopic E/spl)-C transcript accumulation and promoter activity. Wing imaginal discs from late third instar larvae are oriented with anterior to the left and ventral toward the top. $(A, B)$ Transcript accumulation from the endogenous $E(s p l) m 4$ gene. Larvae of the genotypes $w^{1118}(A)$ and $\mathbf{P} /$ ry $^{+}$, hsp $70-$ Notch(intra) $] 2 ; r^{506}(B)$ were subjected to heat shock treatment. Wing imaginal discs were isolated and a digoxygenin-labeled antisense RNA probe corresponding to the $E$ (spl)m4 gene was hybridized to whole mount preparations. $(C-F)$ Activity of $\mathrm{E}(\mathrm{spl})-\mathrm{C}$ promoter-reporter fusion genes. $(C, D)$ Larvae of the genotypes $\left.w^{1118} ; \mathrm{P} / w^{+}, m 4-1 a c Z\right]-96 A(C)$ and $w^{1118} ; \mathrm{P} / \mathrm{w}^{+}, \mathrm{m} 4-$ lacZ $]-96 A ; \mathrm{P}\left[\mathrm{ry}^{+}\right.$, hsp $70-$ Notch(intra) $/ 3(D)$ were dissected after heat shock treatment, and imaginal discs were stained to detect $\beta$-galactosidase activity. Results comparable to those shown were observed with all four independent $\mathrm{P} / \mathrm{m} 4-\mathrm{lac} Z]$ transgene insertions tested. $(E, F)$ Larvae of the genotypes $w^{1118} ; \mathrm{P} / \mathrm{w}^{+}, \mathrm{m8-2.61]} /+(E)$ and $\mathrm{w}^{1118} /+$ (or $\left.+/ Y\right)$; $\mathrm{P} /$ ry $^{+}$, hsp $70-$ Notch(intra) $\left./ 2 / \mathrm{P} / \mathrm{w}^{+}, \mathrm{m8-2.61}\right] ; \mathrm{ry}^{506} /+|F|$ were subjected to heat shock treatment, and imaginal discs were isolated and stained to reveal $\beta$-galactosidase activity. 
A

$\mathrm{E}(\mathrm{spl}) \mathrm{m} 4 \mathrm{~S} 1^{\prime}(-84)$

E(spl)m4 S2' (-287)

E(spl)m4 S3 (-317)

E(spl)m8 S1' (-180)

$\mathrm{E}(\mathrm{spl}) \mathrm{m} 8 \mathrm{~S} 3(-615)$

$E(s p l) m \gamma S 1^{\prime}(-263)$

$E(s p l) m \gamma$ S2 (-293)

$\mathrm{E}(\mathrm{spl}) \mathrm{m} \gamma \mathrm{S3}(-488)$

$\mathrm{E}(\mathrm{spl}) \mathrm{m} \gamma \mathrm{S}$ 4' (-665)

CONSENSUS
CACCGAGTGTGGGAAACTACAAG GCAGGATCGTGAGAAACGAGACT CCGAAACTGTGGGAACTGGTAGA

CTCGTGGCGTGGGAACCGAGCTG AAAATTGTGTGAGAAACTTACTT GGGGCACTGTGGGAACGGAAAGA

CCAGGATCGTGGGAAACACTTTC GAGTCGATGTGAGAAACCGAGTA CCGCTATCGTGGGAACCCCGGAG ATGATCCTGTGGGAACATTGCTC

YGTGG $_{A}$ GAAA $_{C}$

C

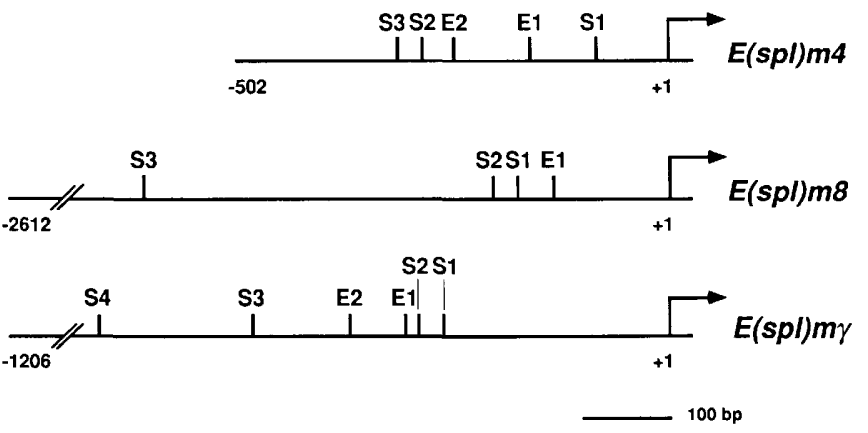

Figure 2. The proximal upstream regions of three genes of the $\mathrm{E} / \mathrm{spl} \mid-\mathrm{C}$ include binding sites for the $\mathrm{Su}(\mathrm{H})$ protein. $(A)$ Alignment of predicted $\mathrm{Su}(\mathrm{H})$ binding sites and surrounding sequences in the $5^{\prime}$ flanking regions of $E(s p l) m 4, E(s p l) m 8$, and $E(s p l) m \gamma$. Binding sites are numbered (S1, etc.) in order of increasing distance upstream of the transcription start site; negative numbers in parentheses represent the position of the 5'-most $G$ residue of each site. Site numbers include a prime symbol when the sequence shown is from the antisense strand. The consensus derived from the aligned sequences (bold) appears at bottom. (B) Alignment of "paired" Su(H) binding sites and surrounding sequences in three $\mathrm{E}$ (spl)-C genes. Negative numbers represent the positions of the first and last nucleotides of each sequence shown. Horizontal arrows at top indicate the opposite orientations of the left and right $\mathrm{Su}(\mathrm{H})$ sites (bold) in each pair; the identical 30-bp spacing of the first $\mathrm{G}$ in each site is indicated at bottom. An invariant hexamer motif (GAAAGT or its complement ACTTTC) that appears between each pair of Su(H) sites is shown boxed; we refer to this as the SPS $[\underline{S} u(H)$ paired site] hexamer. This configuration of binding sites, including the SPS hexamer sequence, has been conserved in the proximal upstream region of a mouse homolog of the E(spl)-C bHLH genes, HES-1. Known binding sites for bHLH repressor proteins in $E$ (spl)m 8 and HES-1 are indicated by underlining of the "N box" (CACNAG) core consensus sequence. $(C)$ Schematic diagrams of the proximal upstream regions of the $E(\operatorname{spl}) \mathrm{m} 4, E(\operatorname{spl}) \mathrm{m} 8$, and $E(\operatorname{spl}) \mathrm{m} \gamma \mathrm{genes}$. Illustrated for each promoter is the interspersion of multiple $\mathrm{Su}(\mathrm{H})$ binding sites ("' $\mathrm{S}$ ") with one or two known $[E(\mathrm{spl}) \mathrm{m} 4, E(\mathrm{spl}) \mathrm{m} 8]$ or predicted $[E(s p l) m \gamma]$ E box binding sites ("E") for proneural bHLH activator proteins. Sequence data for $E(s p l) m 4$ are from Singson et al. (1994) and A. Singson and J.W. Posakony, unpubl.; for E(spl)m8, Klämbt et al. (1989) and A.M. Bailey and J.W. Posakony, unpubl.; for $E(s p l) m \gamma$, Delidakis and Artavanis-Tsakonas (1992).

ure $3 \mathrm{~A}$ shows that purified GST-Su(H) interacts efficiently with radiolabeled oligonucleotide probes representing each of the 10 putative binding sites we identified in the $\mathrm{E}(\mathrm{spl})-\mathrm{C}$. $\mathrm{Su}(\mathrm{H})$ protein synthesized in rabbit reticulocyte lysates behaves similarly in this assay (data not shown). In contrast, $E(s p l) m 4$ probes carrying a single nucleotide change in the $\mathrm{Su}(\mathrm{H})$ binding site consensus sequence $\left(\mathrm{GTG}^{\mathrm{G}} /{ }_{\mathrm{A}} \mathrm{GAA}\right.$ to $\mathrm{GTG}^{\mathrm{G}} /{ }_{\mathrm{A}} \mathrm{CAA}$ ) are not bound detectably (Fig. 3A). The results of these direct DNA-binding assays were corroborated by the competition assays shown in Figure 3B. Su(H) binding to the $E(s p l) m 4 \mathrm{~S} 1$ probe is reduced strongly in the presence of unlabeled oligonucleotides that contain wild-type $\mathrm{Su}(\mathrm{H})$ sites, whereas probes carrying single base mutations in the binding site consensus sequence fail to compete. It should be noted that the $E(s p l) m 8 \mathrm{~S} 3$ site has been recognized previously by Tun et al. (1994) and shown to be bound in vitro by the mouse homolog of $\mathrm{Su}(\mathrm{H}), \mathrm{RBP}-\mathrm{J \kappa}$.

A novel feature of the organization of $\mathrm{E}(\mathrm{spl})-\mathrm{C}$ promoters emerged when we examined the arrangement of $\mathrm{Su}(\mathrm{H})$ binding sites in the three genes we have studied. Figure $2 \mathrm{~B}$ shows that in each gene two of the $\mathrm{Su}(\mathrm{H})$ binding sites constitute an inverted, precisely spaced repeat in which the $5^{\prime}$-most $\mathrm{G}$ of the core sequence $\mathrm{GTG}^{\mathrm{G}}$ / ${ }_{A}$ GAA is separated by exactly $30 \mathrm{bp}$. We also note that the sequence between the paired sites in all three genes includes the hexamer GAAAGT, although its position and orientation with respect to the $\mathrm{Su}(\mathrm{H})$ binding sites is variable (see Fig. 2B). That both the paired site arrangement and the intervening hexamer sequence have functional significance is strongly suggested by their apparent conservation in the proximal upstream region of HES-1, a mouse homolog of the E(spl)-C bHLH genes (see Fig. 2B). In this mouse gene the paired sites are spaced by $29 \mathrm{bp}$ instead of $30 \mathrm{bp}$, and in addition, a second copy of the hexamer sequence appears adjacent to the leftward site of the pair.

Interestingly, situated close to the rightward member of the paired $\mathrm{Su}(\mathrm{H})$ binding sites in the upstream regions of $E$ (spl) $\mathrm{m} 8$ and HES-1 are sequences that have been proposed to mediate transcriptional autorepression of these genes (Kramatschek and Campos-Ortega 1994; Takebayashi et al. 1994). A tandem repeat of the " $\mathrm{N}$ box" motif (CACNAG), to which E(spl)-C bHLH proteins bind in 
A
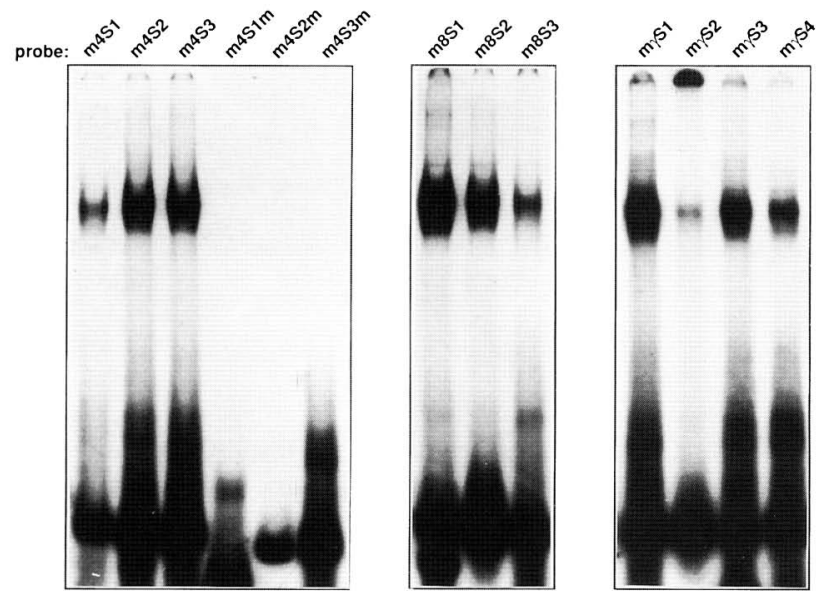

B

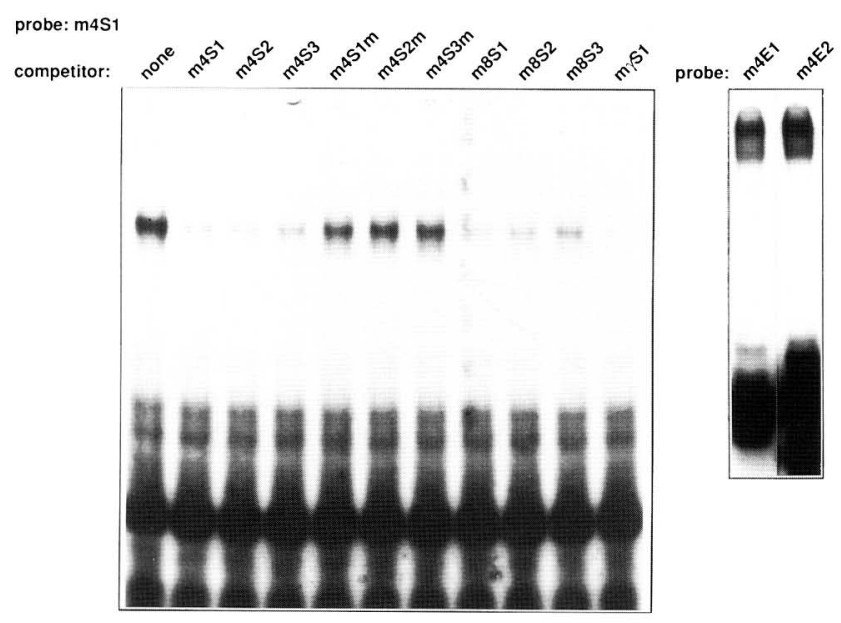

Figure 3. Electrophoretic mobility-shift assays of DNA binding by $\mathrm{Su}(\mathrm{H})$ and proneural proteins. $(A)$ Radiolabeled DNA probes containing the consensus sequence $\mathrm{GTG}^{\mathrm{G}} /{ }_{\mathrm{A}} \mathrm{GAA}$ and surrounding nucleotides corresponding to each indicated site are bound efficiently in vitro by the $\mathrm{Su}(\mathrm{H})$ protein. Probes are named according to designations in Fig. 2A. (Left) No binding activity is observed with mutant versions (indicated by an " $\mathrm{m}$ ") of each $m 4$ probe; these contain a single base pair mutation of the $\mathrm{Su}(\mathrm{H})$ consensus sequence $\left(\mathrm{GTG}^{\mathrm{G}} /{ }_{\mathrm{A}} \mathrm{GAA}\right.$ to $\left.\mathrm{GTG}^{\mathrm{G}} /{ }_{\mathrm{A}} \mathrm{CAA}\right)$. $(B)$ Various unlabeled $\mathrm{Su}(\mathrm{H})$ binding site-containing probes compete effectively, at a 20 -fold molar excess, for the interaction between the $\mathrm{Su}(\mathrm{H})$ protein and the $E(\mathrm{spl}) \mathrm{m} 4 \mathrm{~S} 1$ radiolabeled probe. Mutant probes, not bound by $\mathrm{Su}(\mathrm{H})$ in direct binding assays (see $A$ ), compete poorly. $(C)$ Radiolabeled DNA probes containing the E1 and E2 E box sites, previously identified in the proximal upstream region of $E(\mathrm{spl}) \mathrm{m} 4$ (Singson et al. 1994), are bound efficiently by hetero-oligomeric complexes of the ac and da proteins.

vitro (Tietze et al. 1992), is positioned only a single base pair from the $\mathrm{S} 1 \mathrm{Su}(\mathrm{H})$ binding site of $E(\mathrm{spl}) \mathrm{m} 8$ (see Fig. 2B). Similarly, one of the paired $\mathrm{Su}(\mathrm{H})$ binding sites in
HES-1 overlaps an $\mathrm{N}$ box site that is bound in vitro by the HES-1 protein (Takebayashi et al. 1994) (see Fig. 2B).

The overall organization of $\mathrm{Su}(\mathrm{H})$ binding sites in the proximal upstream regions of $E(s p 1) m 4, E(s p l) m 8$, and $E(s p l) m \gamma$ is illustrated in Figure 2C. All three genes have at least one "lone" $\mathrm{Su}(\mathrm{H})$ site in addition to the paired sites. Another important feature of these promoters is the presence of one or two "E box" binding sites for the proneural bHLH activator proteins ac, sc, and da (Singson et al. 1994). These sites, which have also been found in the upstream region of $E(\mathrm{spl}) \mathrm{m} 7$, mediate direct transcriptional activation of $\mathrm{E}(\mathrm{spl})-\mathrm{C}$ genes in the proneural clusters of the wing disc and in the ventral ectoderm of the embryo (Kramatschek and Campos-Ortega 1994; Singson et al. 1994).

Both $\mathrm{Su}(\mathrm{H})$ gene activity and intact $\mathrm{Su}(\mathrm{H})$ binding sites are necessary for normal $E$ (spl)-C promoter activity in imaginal tissues

That the $\mathrm{Su}(\mathrm{H})$ protein binds in vitro to specific sequences in the upstream regions of $E(\mathrm{spl}) \mathrm{m} 4, E(\mathrm{spl}) \mathrm{m} 8$, and $E(s p l) m \gamma$ is consistent with the possibility that it directly regulates transcription of these genes in vivo. To address this question, we constructed a derivative of the $m 4-l a c Z$ promoter-reporter fusion gene, $m 4 S 1,2,3 m-$ $l a c Z$, in which each of the three $\mathrm{Su}(\mathrm{H})$ binding sites has been mutated at a single bp $\left(\mathrm{GTG}^{\mathrm{G}} /{ }_{\mathrm{A}} \mathrm{GAA}\right.$ changed to $\mathrm{GTG}^{\mathrm{G}} /{ }_{\mathrm{A}} \mathrm{CAA}$ ), such that they would no longer be bound by $\mathrm{Su}(\mathrm{H})$ in vitro (Fig. 3A,B). Wing imaginal discs isolated from transgenic larvae carrying this mutant construct do exhibit detectable $\beta$-galactosidase activity in a small number of cells that correspond in position to the proneural clusters, but the overall level of reporter gene activity in the clusters is severely reduced as a consequence of mutating the $\mathrm{Su}(\mathrm{H})$ binding sites (Fig. 4A,B). This effect extends to other larval tissues. Throughout the eye-antenna imaginal disc and in the optic lobes of the brain, the activity of the mutant reporter gene (Fig. $4 \mathrm{H}, \mathrm{K})$ is markedly reduced relative to the wild-type construct (Fig. 4G,J). Thus, the integrity of its $\mathrm{Su}(\mathrm{H})$ binding sites is necessary for normal in vivo levels of activation of a 510-bp proximal promoter fragment from the $E(s p l) m 4$ gene.

We then investigated whether the activity of the endogenous $S u(H)$ gene is required in trans for proper expression of the wild-type $m 4-1 a c Z$ reporter construct. We found that in certain imaginal tissues a loss of $\mathrm{Su}(\mathrm{H})$ function has a similar effect on the activity of the $m 4$ reporter gene as mutating its three $\mathrm{Su}(\mathrm{H})$ binding sites. Thus, the activity of the reporter is reduced significantly in the retinal field of the eye-antenna imaginal disc and in the optic lobes of the brain in $S u(H)$ mutant larvae that are trans-heterozyogous for the null alleles $\mathrm{Su}(H)^{A R 9}$ and $\mathrm{Su}(H)^{S F 8}$ (Fig. $\left.4 \mathrm{I}, \mathrm{L}\right)$. Likewise, the activity of the $E($ spl $) m 8$ promoter-reporter fusion gene is clearly reduced in the brain of $\mathrm{Su}(\mathrm{H})$ mutant animals (data not shown).

In other imaginal tissues such as the wing disc, m4- 

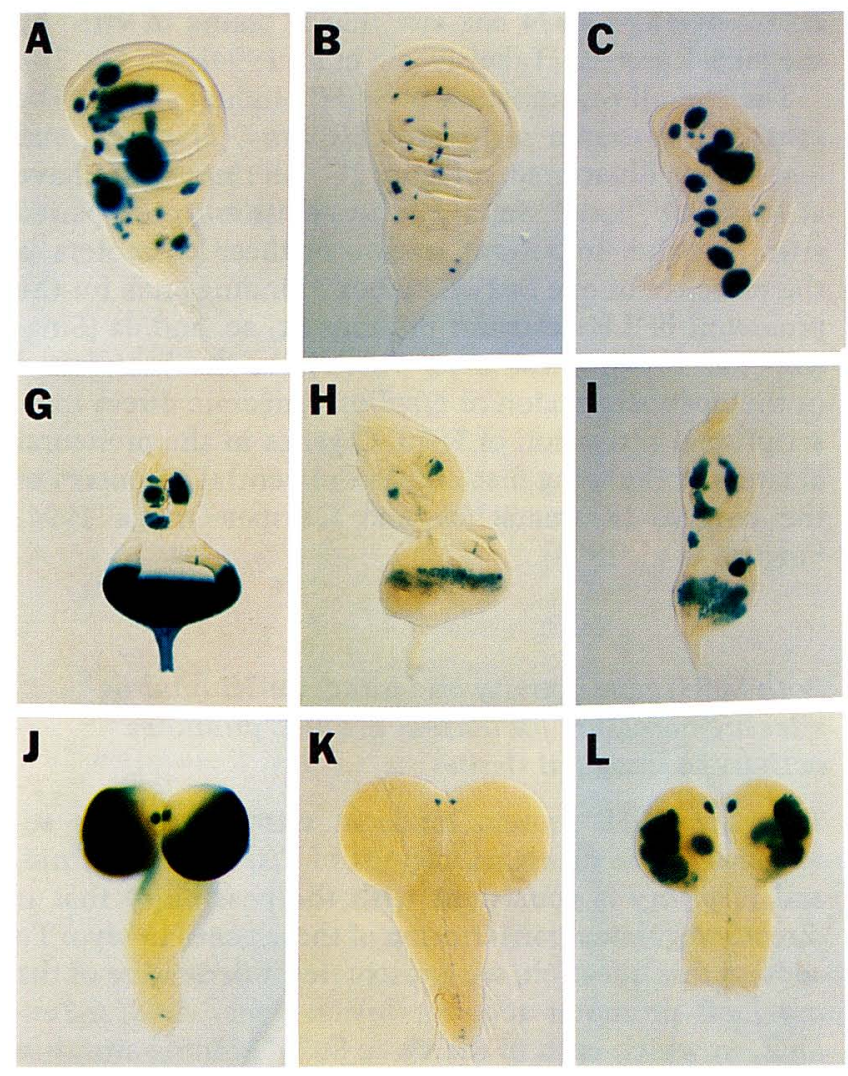
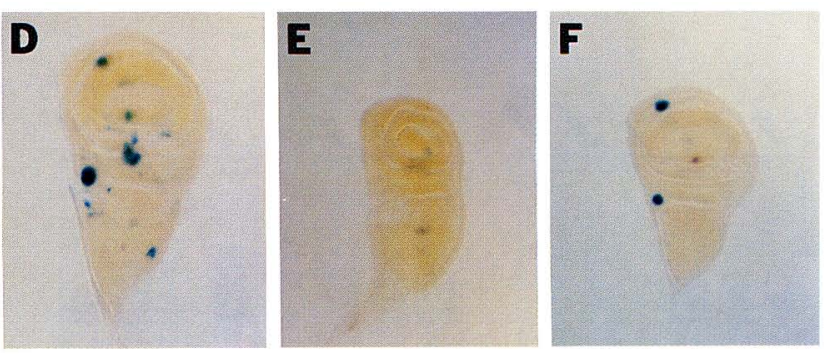

Figure 4. Cis- and trans-regulation of E(spl)-C promoter-reporter fusion genes. Imaginal discs and brains were isolated from late third instar larvae and stained to detect $\beta$-galactosidase activity. $(A-C)$ Wing imaginal discs. $(G-I)$ Eye-antenna imaginal discs, with the anterior of the prospective retina toward the top. $(J-L)$ Larval brains, dorsal views, with anterior toward the top. Tissue is of the following genotypes: $(A, G, J) \mathrm{w}^{1118} ; \mathrm{P} / \mathrm{W}^{+}, \mathrm{m} 4$ lacZl-113A. Nine of ten lines tested displayed expression patterns and levels comparable to those shown. $(B, H, K) \mathrm{w}^{1118}$; $\left.P / w^{+}, m 4 S 1,2,3 m-l a c Z\right]-1 B$. Six of nine lines tested displayed expression patterns and levels comparable to those shown. $\left.(C, I, L) \mathrm{w}^{1118} ; \mathrm{Su}(H)^{A R 9} / \mathrm{Su}(H)^{\mathrm{SF8}} ; \mathrm{P} / \mathrm{w}^{+}, \mathrm{m} 4-1 \mathrm{acZ}\right)-113 A .(D)$ $w^{1118} ; P\left[w^{+}, m 4 E 1,2 m-l a c Z\right]-8$. Eight of nine lines tested displayed expression patterns and levels comparable to those shown. $(E) w^{1118} ; \mathrm{Su}(H)^{A R 9} / \mathrm{Su}(H)^{S F 8} ; \mathrm{P} / \mathrm{w}^{+}, \mathrm{m} 4 E 1,2 \mathrm{~m}-\mathrm{lac} Z \mathrm{~J}-8$. (F) $\left.s c^{10-1} w^{1118} / Y ; P / w^{+}, m 4-l a c Z\right]-113 A$.

lacZ (Fig. 4C) and m8-lacZ (data not shown) reporter gene expression is, if anything, increased in a $\mathrm{Su}(H)^{-}$ background. Moreover, it is noteworthy that even in the antenna disc and the larval brain, where loss of $S u(H)$ function decreases the activity of the $E(\mathrm{spl}) \mathrm{m} 4$ promoter, the effect is not as great as that of mutating the $\mathrm{Su}(\mathrm{H})$ binding sites (Fig. 4G-L). These results imply that $\mathrm{Su}(\mathrm{H})$ activity negatively regulates one or more additional transcriptional activators of $\mathrm{E} / \mathrm{spl})$-C genes. We will consider this question in detail in the next section. In any case, the observations that proper levels of $m 4-1 a c Z$ reporter gene expression require intact $\mathrm{Su}(\mathrm{H})$ binding sites in all imaginal tissues examined (Fig. $4 \mathrm{~B}, \mathrm{H}, \mathrm{K}$ ), and $\mathrm{Su}(\mathrm{H})$ gene activity in at least some tissues (Fig. 4I,L), strongly support the conclusion that $\mathrm{E}(\mathrm{spl})$ - $\mathrm{C}$ genes are normally subject to direct transcriptional activation by $\mathrm{Su}(\mathrm{H})$ in vivo.

\section{Dual transcriptional activation of $E(s p l)$-C genes by $\mathrm{Su}(H)$ and by proneural proteins}

In interpreting our results concerning $\mathrm{Su}(\mathrm{H})$ regulation of E(spl)-C gene transcription in imaginal tissues, we found it essential to consider the contribution of proneural bHLH proteins to the activation of these genes (Singson et al. 1994). We hypothesized that the residual expression of the mutant reporter gene $m 4 S 1,2,3 m-l a c Z$ in wild-type wing discs (Fig. 4B), as well as the very strong expression of the wild-type $\mathrm{m} 4-\mathrm{lacZ}$ reporter in $\mathrm{Su}(\mathrm{H})^{-}$

wing discs (Fig. 4C), could result, at least in part, from proneural protein regulation of the $m 4$ promoter. We conducted a series of experiments to test this hypothesis directly.

First, we verified that two $E$ box sequences in the $E(s p l) m 4$ upstream region (E1 and E2; see Fig. 2C), previously predicted to interact with proneural bHLH proteins (Singson et al. 1994), are in fact bound by these proteins in vitro. We found that, as with similar sites in the $E(\mathrm{spl}) \mathrm{m} 7$ and $E(\mathrm{spl}) \mathrm{m} 8$ promoters (Singson et al. 1994), labeled oligonucleotide probes containing the $E(s p l) m 4 \mathrm{E} 1$ and $\mathrm{E} 2$ sites are retarded in electrophoretic mobility in the presence of a combination of GST-ac and GST-da proteins (Fig. 3C).

We then sought to demonstrate that these proneural protein binding sites are required in vivo for the normal activity of the $E(s p l) m 4$ promoter. We prepared a second mutant $m 4-l a c Z$ reporter gene, $m 4 E 1,2 m-l a c Z$, in which both $\mathrm{E}$ box binding sites were mutated from CAGGTG to CCGGTT; the three $\mathrm{Su}(\mathrm{H})$ binding sites are intact in this construct. As shown in Figure 4D, the expression of the mutant reporter in the proneural clusters of the wing imaginal disc is strongly reduced relative to its wild-type counterpart (Fig. 4A). A similar result was obtained with an $m 8-1 a c Z$ reporter gene that carries a mutation in its single $\mathrm{E}$ box proneural protein binding site (Kramatschek and Campos-Ortega 1994; Singson et al. 1994) (data not shown). Nevertheless, the E box mutant versions of both the $m 4$ and $m 8$ promoters retain 
some capacity to drive diffuse reporter gene expression in proneural clusters (Fig. 4D; data not shown). We suggest that this represents the normal activation of these promoters by $\mathrm{Su}(\mathrm{H})$ (see below). Conversely, we believe that the punctate residual expression described above for the $m 4 S 1,2,3 m-l a c Z$ mutant reporter gene (Fig. 4B) reflects the action of proneural bHLH activators.

The foregoing results provide the basis for interpreting the very strong expression of the wild-type $m 4-l a c Z$ reporter gene in the proneural clusters of $\mathrm{Su}(\mathrm{H})^{-}$wing discs (Fig. 4C), which at first appears inconsistent with the conclusion that $\mathrm{Su}(\mathrm{H})$ is a normal activator of E(spl)-C gene transcription. Previously, we have shown that null mutations in $\mathrm{Su}(H)$ lead to the commitment of most or all proneural cluster cells in the wing disc to the SOP cell fate (Schweisguth and Posakony 1992), and that these cells exhibit high levels of proneural protein expression and transcriptional regulatory activity (Schweisguth and Posakony 1994). Thus, we believed it likely that in $\mathrm{Su}(\mathrm{H})^{-}$discs the $E(\mathrm{spl}) \mathrm{m} 4$ promoter should be subject to strong activation by proneural proteins through its $E$ box binding sites. Introducing the $E$ box mutant construct $m 4 E 1,2 m-l a c Z$ into a $S u(H)^{-}$background provided a way to test this expectation. We find that the activity of the $\mathrm{m} 4-\mathrm{lacZ}$ reporter gene in $\mathrm{Su}(\mathrm{H})^{-}$ wing discs is almost entirely dependent on the integrity of the E1 and E2 proneural protein-binding sites (Fig. 4, cf. $\mathrm{C}$ with $\mathrm{E}$ ). This experiment also demonstrates that the residual expression of the $m 4 E 1,2 m-l a c Z$ mutant reporter gene in the proneural clusters of the wild-type wing disc is $\mathrm{Su}(H)$ dependent (Fig. 4, cf. D with E).

$m 4-l a c Z$ reporter gene expression in $\mathrm{Su}(\mathrm{H})^{-}$eye-antenna imaginal discs and optic lobes is likewise dependent on the integrity of the E1 and E2 sites (data not shown), suggesting that in these tissues as well the $E$ (spl)m4 promoter is subject to dual transcriptional regulation by both $\mathrm{Su}(\mathrm{H})$ and bHLH activators. It is likely that the atonal (ato) bHLH protein acts as the proneural regulator of $\mathrm{E}(\mathrm{spl})-\mathrm{C}$ genes in the retina and many of the proneural clusters of the eye-antenna disc (Jarman et al. 1993, 1994; Singson et al. 1994).

Finally, we investigated the effect of loss of proneural gene activity on the expression of the wild-type $m 4-l a c Z$ and $m 8-1 a c Z$ reporters in the wing disc. We introduced both constructs into animals of the $s c^{10-1}$ genotype [this mutation inactivates both $a c$ and $s c$ (Lindsley and Zimm 1992)l, and found that the activity of both the $E(s p l) m 4$ and $E(s p l) \mathrm{m} 8$ promoters in external sensory organ proneural clusters is completely extinguished in this background (Fig. 4F; data not shown). m4-lacZ reporter gene expression is retained only in two positions at which ato-dependent, ac/sc-independent chordotonal organ precursors are developing (Jarman et al. 1993) (Fig. 4F). Thus, loss of $a c$ and $s c$ proneural gene activity in trans has a more severe effect on the activity of the $E(\mathrm{spl}) \mathrm{m} 4$ and $E$ (spl)m 8 promoters in the wing disc than mutating proneural protein binding sites in cis (Fig. 4, cf. D with F). This finding has the important implication that $\mathrm{Su}(\mathrm{H})$-mediated activation of these promoters in external sensory organ proneural clusters is, at some level, depen- dent on the activity of the proneural genes $a c$ and $s c$ (see Discussion).

The transcriptional response of $E(s p l)$ - $C$ genes to $N$ receptor activity requires intact $\mathrm{Su}(\mathrm{H})$ binding sites in cis and $\mathrm{Su}(\mathrm{H})$ gene function in trans

Having found that mutation of its $\mathrm{Su}(\mathrm{H})$ binding sites severely diminishes the normal in vivo activity of the $E(s p l) m 4$ promoter (Fig. 4), we turned to the question of whether the mutant promoter is likewise compromised in its capacity to respond to the expression of an activated form of the $\mathrm{N}$ receptor. We found that the mutant $E(s p l) m 4$ reporter construct, $m 4 S 1,2,3 m-1 a c Z$, appears completely insensitive to expression of Notch(intra) (Fig. 5A,B, cf. with Fig. 1C,D). We conclude that intact $\mathrm{Su}(\mathrm{H})$ binding sites are essential for the activation of the $E(s p l) m 4$ promoter that results from hyperactivity of the $\mathrm{N}$ receptor.

We also examined the effect of Notch(intra) expression on the accumulation of endogenous $E(s p l) m 4$ transcripts in larvae trans-heterozygous for the $\mathrm{Su}(\mathrm{H})$ null alleles $S u(H)^{A R 9}$ and $S u(H)^{S F 8}$. Figure 5, C and D, shows that in $\mathrm{Su}(H)$ mutant wing discs, the elevated and ectopic accumulation of $E$ (spl)m4 RNA observed in a $\mathrm{Su}(H)^{+}$background (see Fig. 1A,B) is abolished, indicating that $\mathrm{Su}(H)$ activity is required at some level to mediate this effect. A similar experiment was performed to investigate whether $S u(H)$ gene activity is required for the response of the $E(\mathrm{spl}) \mathrm{m} 8$ reporter gene to hyperactivity of the $\mathrm{N}$ receptor (see Fig. 1E,F). We found that in imaginal discs of larvae lacking $\mathrm{Su}(H)^{+}$function, expression of Notch(intra) fails to elicit a detectable response of the $m 8-1 a c Z$ reporter gene (Fig. $5 \mathrm{E}, \mathrm{F})$. $\mathrm{Su}(\mathrm{H})$ gene activity is necessary, then, for the responses of both the endogenous $E(s p l) \mathrm{m} 4$ gene and an $E(s p l) \mathrm{m} 8$ promoterreporter fusion gene to artificial elevation of the activity of the $N$ signaling pathway.

These results strongly support the conclusion that, in proneural cluster cells of the wing imaginal disc, transcription of $\mathrm{E}(\mathrm{spl})-\mathrm{C}$ genes is activated directly by $\mathrm{Su}(\mathrm{H})$ in response to a $\mathrm{N}$-mediated signal.

Concomitant overexpression of Hairless antagonizes the effect of Notch(intra) expression on $E$ (spl)-C promoter activity

We and other investigators have shown previously that, in successive alternative cell fate decisions of adult peripheral neurogenesis, $H$ acts antagonistically to the activity of the $\mathrm{N}$ receptor (Bang et al. 1995; A.M. Bailey and J.W. Posakony, unpubl.), to $S u(H)$ (Ashburner 1982; Schweisguth and Posakony 1994), and to the genes of the E(spl)-C, including gro (Knust et al. 1987; Bang et al. 1995). In vitro, $H$ protein specifically associates with $\mathrm{Su}(\mathrm{H})$ and inhibits its DNA-binding activity; furthermore, in transient transfection experiments in cultured cells, $H$ antagonizes the capacity of $\mathrm{Su}(\mathrm{H})$ to function as a transcriptional activator (Brou et al. 1994). These findings prompted us to evaluate the ability of $H$ to antago- 

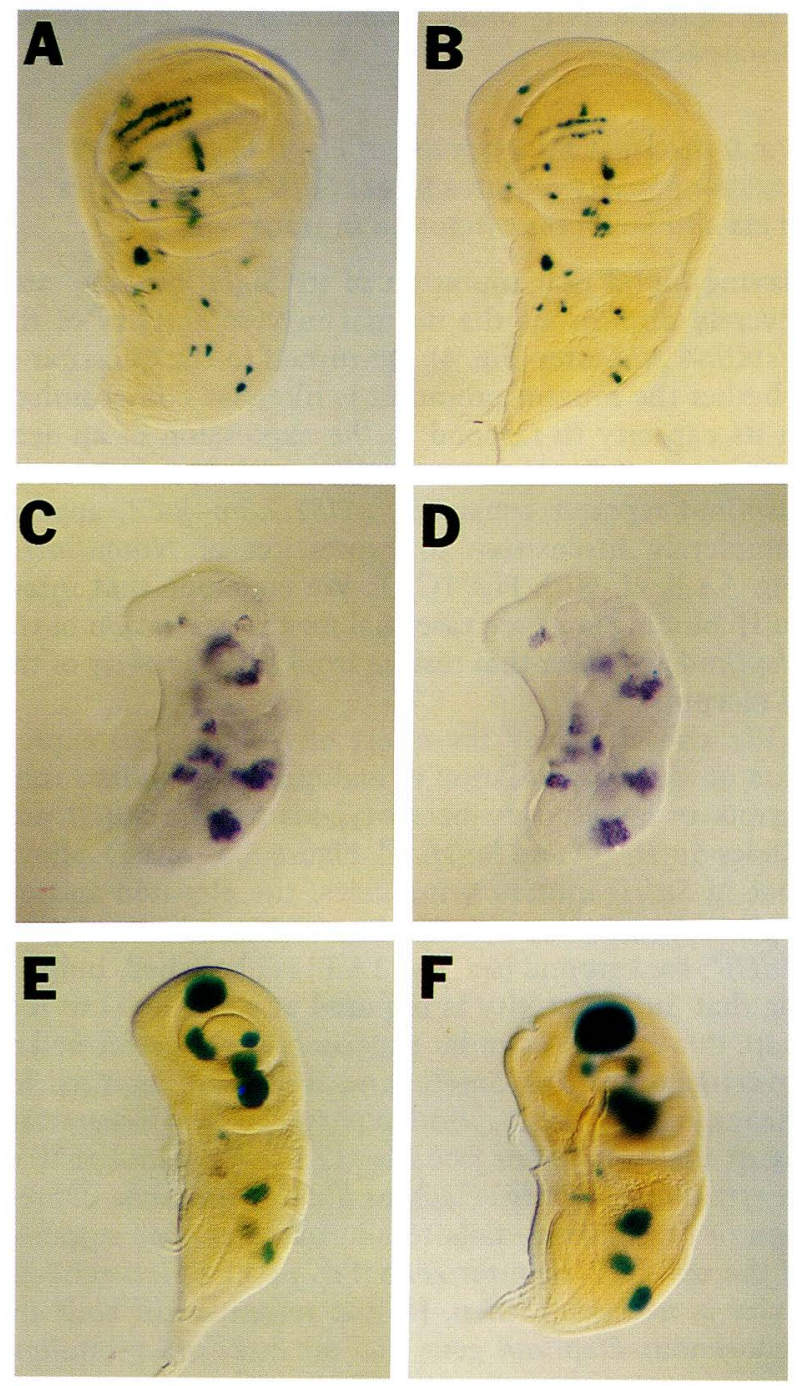

Figure 5. Response of $\mathrm{E}(\mathrm{spl})-\mathrm{C}$ gene expression to $\mathrm{N}$ receptor activity is mediated by $\mathrm{Su}(\mathrm{H})$. Wing imaginal discs were isolated from late third instar larvae. $\langle A, B)$ Integrity of $\mathrm{Su}(\mathrm{H})$ binding sites is necessary for the response of an $E(s p l) m 4$ promoter fragment to expression of Notch(intra). $\beta$-Galactosidase activity was assayed in tissue of the following genotypes: $(A) \mathrm{w}^{1118}$; $\left.P / w^{+}, m 4 S 1,2,3 m-l a c Z\right]-1 B .(B) w^{1118} ;$ Plry ${ }^{+}$, hsp $70-$ Notch(intra) $\left.] 2 ; P / w^{+}, m 4 S 1,2,3 m-l a c Z\right]-1 B$, following heat shock treatment. The mutant promoter fragment fails to respond to expression of $N o t c h($ intra) in five of five lines tested. $(C-F) S u(H)$ gene activity is required to mediate $\mathrm{E}(\mathrm{spl})-\mathrm{C}$ promoter activation in response to expression of Notch(intra). $(C, D)$ Larvae of the genotypes $\mathrm{Su}(H)^{A R 9} / \mathrm{Su}(H)^{S F 8}(C)$ and $\mathrm{Su}(H)^{A R 9} / \mathrm{Su}(H)^{S F 8}$; $P\left[\mathrm{ry}^{+}\right.$, hsp70-Notch(intra) $] 3(D)$ were subjected to heat shock. Imaginal discs were isolated, and accumulation of transcripts from the endogenous $E(s p l) m 4$ gene was analyzed by in situ hybridization with a digoxygenin-labeled antisense RNA probe. Expression of Notch(intra) fails to induce detectable misexpression of $E(s p l) m 4$ in $S u(H)$ mutant tissue (cf. with Fig. 1A,B). (E,F) Larvae of the genotype $\left.w^{1118} ; S u(H)^{A R 9} P / w^{+}, m 8-2.61\right] / S u$ $(H)^{S F 8}$, P/ry ${ }^{+}$, hsp $70-N o t c h($ intra $\left.)\right] 3 /+$ were allowed to develop at $25^{\circ} \mathrm{C}(E)$ or subjected to heat shock $(F)$. Imaginal discs were isolated and stained to reveal $\beta$-galactosidase activity. Expression of Notch(intra) fails to induce ectopic activity of the $m 8-$ lac $\mathrm{Z}$ promoter-reporter fusion gene in $\mathrm{Su}(\mathrm{H})$ mutant tissue (cf. with Fig. 1E,F). nize $N$ signaling-dependent activation of $\mathrm{E}(\mathrm{spl})-\mathrm{C}$ gene expression in vivo. Figure 6A,B shows that concomitant overexpression of $H$ strongly suppresses the ectopic activation of the $m 8-1 a c Z$ reporter gene that results from expression of Notch(intra) (Fig. 6, cf. with Fig. 1E,F). We propose from these results that, in imaginal discs, $\mathrm{H}$ antagonizes the activity of the $N$ signaling pathway by inhibiting the ability of $\mathrm{Su}(\mathrm{H})$ to activate transcription of E/spl)-C and perhaps other genes.

\section{Discussion}

N pathway activity transcriptionally activates E(spl)-C gene expression

We have shown here that the activity of the $N$ cell-cell signaling pathway results in the activation of $\mathrm{E}(\mathrm{spl})-\mathrm{C}$ gene expression by a transcriptional mechanism, and that the promoters of individual $\mathrm{E}(\mathrm{spl})-\mathrm{C}$ genes are independently responsive to $N$ signaling. These findings provide a molecular basis for the observation of Jennings et al. (1994) that $\mathrm{E}$ (spl)-C bHLH protein accumulation in the neurogenic ectoderm of the embryo is regulated positively by the $N$ pathway. Our results also demonstrate that a non-bHLH transcription unit in the E(spl)-C, $m 4$, is likewise subject to $N$ signal-dependent transcriptional activation.

\section{Regulation of $\mathrm{Su}(\mathrm{H})$ activity by the $\mathrm{N}$ receptor}

An important implication of our data is that the transcriptional regulatory activity of $\mathrm{Su}(\mathrm{H})$ is regulated in vivo by the activity of the $\mathrm{N}$ receptor. This is consistent with the evidence reported by Fortini and Artavanis-Tsakonas (1994) that $\mathrm{Su}(\mathrm{H})$ interacts directly with the intracellular domain of $\mathrm{N}$, and that the nuclear translocation
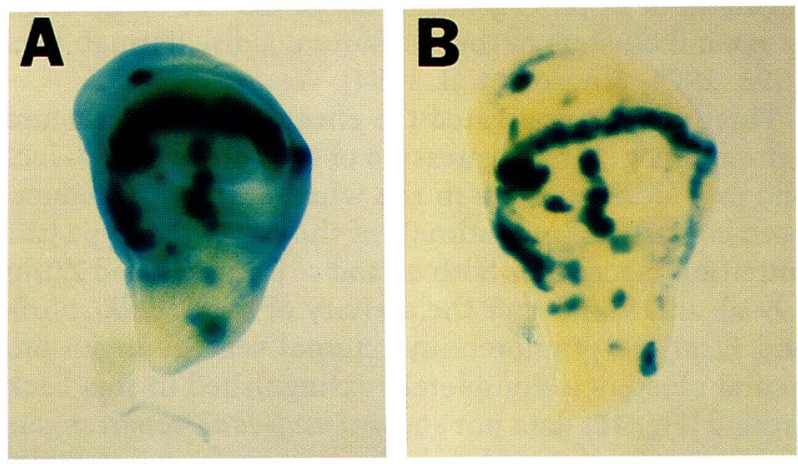

Figure 6. Concomitant overexpression of $H$ suppresses the effect of Notch(intra) expression on the activity of an $m 8-1 a c Z$ promoter-reporter fusion gene. Larvae of the following genotypes were subjected to heat shock: $(A) \mathrm{W}^{1118} ; \mathrm{P} / \mathrm{W}^{+}, \mathrm{m8-2.61]/}$ ${ }_{+} ; P\left[\right.$ ry $^{+}$, hsp $70-N o t c h($ intra $\left.)\right] 3 /+.(B) w^{1118} ; P\left[W^{+}, m 8-2.61\right] /$ ${ }_{+} ; P\left[r y^{+}, h s p 70-N o t c h(\right.$ intra $\left.\left.)\right] 3 / P / w^{+}, H s-H\right]-3$. Imaginal discs were isolated and stained to reveal $\beta$-galactosidase activity. The ectopic activity of the $m 8-1 a c Z$ reporter that results from the induction of the hsp70-Notch(intra) gene $(A$; see Fig. $1 \mathrm{E}, \mathrm{F})$ is suppressed when a $H s-H$ gene is induced simultaneously $(B)$. 
of $\mathrm{Su}(\mathrm{H})$ is regulated in tissue culture cells by $\mathrm{N}$-mediated cell-cell interaction. It remains to be determined whether nuclear localization of $\mathrm{Su}(\mathrm{H})$ is sufficient to permit its function as a transcriptional activator, or whether an additional regulatory step (e.g., biochemical modification) controlled by the $\mathrm{N}$ signal is required to activate the protein.

\section{$E(s p l)-C$ genes as direct targets of transcriptional activation by $\mathrm{Su}(\mathrm{H})$}

We believe the results presented here strongly support the conclusion that at least some genes of the E/spl|-C are activated directly by the $\mathrm{Su}(\mathrm{H})$ protein in vivo (Fig. 7A). First, $\mathrm{Su}(\mathrm{H})$ binds efficiently and sequence specifically in vitro to each of the multiple sites we have identified in the proximal upstream regions of the $E(s p l) m 4$, $E(s p l) m 8$, and $E(s p l) m \gamma$ genes. Second, expression of $\mathrm{E}$ (spl)-C promoter-reporter fusion genes in the retina ( $m 4-1 a c Z)$ and in the optic lobes ( $m 4-l a c Z, m 8-l a c Z)$ is strongly reduced in a $\mathrm{Su}(H)^{-}$background. Finally, mutation of all three $\mathrm{Su}(\mathrm{H})$ binding sites in the $E(\mathrm{spl}) \mathrm{m} 4$ promoter not only strongly reduces reporter gene expression in the proneural clusters of wild-type wing discs, it also eliminates the responsiveness of the reporter gene to hyperactivity of the $\mathrm{N}$ receptor.

$\mathrm{E}(\mathrm{spl})-\mathrm{C}$ genes are the first in vivo targets of $\mathrm{Su}(\mathrm{H})$ to be defined, and it is noteworthy that our data indicate that the regulatory relationship is positive (i.e., that $\mathrm{Su}(\mathrm{H})$ transcriptionally activates these genes). The Epstein-Barr virus-encoded protein EBNA2 plays an essential role in the transcriptional activation of a number of viral and cellular promoters by CBF1, the human homolog of $\mathrm{Su}(\mathrm{H})$ (Grossman et al. 1994; Henkel et al. 1994). Recent evidence indicates that EBNA2 forms a complex with CBF1 that both masks the repression domain of the latter and brings a powerful activation domain (part of
EBNA2) to the DNA (Hsieh and Hayward 1995). This suggests that the activation of $\mathrm{E}(\mathrm{spl})-\mathrm{C}$ genes by $\mathrm{Su}(\mathrm{H})$ may involve the recruitment of a similar coactivator. It also raises the possibility that $\mathrm{Su}(\mathrm{H})$ may act as a transcriptional repressor (Dou et al. 1994) of other genes in non-SOP cells, or of E(spl)-C genes in SOPs. Indeed, on the basis of their results with CBF1, Hsieh and Hayward (1995) have interpreted the hypomorphic HG36 allele and the hypermorphic S5 allele of $\mathrm{Su}(\mathrm{H})$ as representing a loss or gain of repressive activity, respectively.

\section{Paired $\mathrm{Su}(H)$ binding sites in $E(s p l)-C$ promoters}

The presence of precisely paired $\mathrm{Su}(\mathrm{H})$ binding sites in the proximal upstream regions of $\mathrm{E}(\mathrm{spl})-\mathrm{C}$ genes and of a homologous gene in the mouse (Fig. 2B,C) was an unexpected finding. Genes identified as direct targets of regulation by the mammalian homologs of $\mathrm{Su}(\mathrm{H})$ generally contain a single high-affinity binding site (Grossman et al. 1994; Henkel et al. 1994), and where more than one site is present [e.g., in the Epstein-Barr virus TP1 gene (Meitinger et al. 1994; Waltzer et al. 1994)], they are not arranged in the same inverted fashion or with the same spacing as in the $\mathrm{E}(\mathrm{spl})-\mathrm{C}$ genes. Furthermore, each of the three $\mathrm{E}$ (spl)-C genes we have studied has at least one "lone" Su(H) site in addition to the paired sites. Thus, the functional significance of the paired sites is not yet clear, although the conservation of this arrangement between insects and mammals suggests strongly that it has an important role. Two noteworthy possibilities are that the paired sites permit synergistic interactions between bound $\mathrm{Su}(\mathrm{H})$ monomers, or that they mediate the recruitment of another protein (or proteins) to the promoter. The latter possibility is further suggested by the presence of the conserved hexamer sequence GAAAGT (or its complement ACTTTC) in the region between the paired $\mathrm{Su}(\mathrm{H})$ sites (Fig. 2B).

A
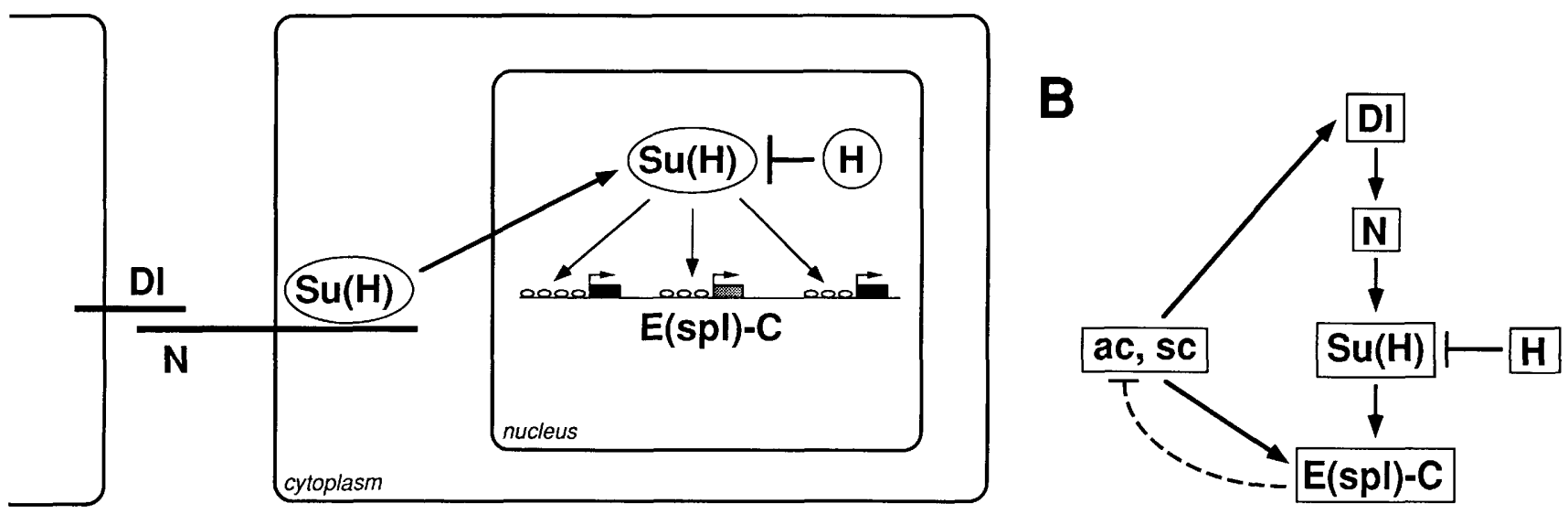

Figure 7. Structure and regulation of the $N$ pathway in adult external sensory organ development. $(A)$ Model for the intracellular transduction of the $\mathrm{N}$-mediated inhibitory signal in an imaginal disc proneural cluster cell (see text for description). (B) Regulatory relationships between proneural genes and the genes of the $N$ pathway. 
It is striking that, in both $E(s p l) m 8$ and HES-1, the rightward $\mathrm{Su}(\mathrm{H})$ binding site of the paired site configuration lies very close to, or overlaps, a binding site for bHLH repressor proteins (Fig. 2B). It has been suggested that these sites mediate an autorepression activity of these genes (Kramatschek and Campos-Ortega 1994; Takebayashi et al. 1994). Perhaps one component of the transcriptional activation of $E(\mathrm{spl}) \mathrm{m} 8$ by $\mathrm{Su}(\mathrm{H})$ [and of HES-1 by the murine homolog of $\mathrm{Su}(\mathrm{H})]$ is the displacement of a bHLH repressor protein from the DNA.

\section{Dual transcriptional activation of E(spl)-C genes in wing disc proneural clusters}

The results described here, together with those of Singson et al. (1994), indicate that genes of the E/spl)-C are subject to at least two modes of transcriptional activation within the proneural clusters of the wing imaginal disc (Fig. 7B). The proneural proteins ac and sc, probably in heterodimeric complexes with da, activate $\mathrm{E}(\mathrm{spl})-\mathrm{C}$ genes directly through one or more high-affinity $\mathrm{E}$ box binding sites in the proximal upstream regions of these genes (Singson et al. 1994) (see Fig. 2C). It is likely that this activation is initially independent of $N$ pathway signaling activity. Activated $\mathrm{Su}(\mathrm{H})$ protein also activates these $\mathrm{E}$ (spl|-C genes directly, through one or more highaffinity $\mathrm{Su}(\mathrm{H})$ binding sites also located in the proximal upstream region (see Fig. 2C). It is probable that this activity is largely or wholly regulated by signaling through the $\mathrm{N}$ receptor.

Taken together with earlier studies, our results offer an explanation for the observation that loss-of-function mutations of the proneural genes have a more drastic effect on $E(\mathrm{spl})-\mathrm{C}$ gene expression than do mutations of the $\mathrm{E}$ box sites that normally mediate direct activation by the proneural proteins (this study; Kramatschek et al. 1994). The activity of the $N$ pathway is not independent of proneural gene activity; in particular, the level of expression of the ligand-encoding gene $D 1$ is regulated positively in neuroblasts and SOPs by the proneural genes (Kunisch et al. 1994; see also Schweisguth and Posakony 1994). Thus, loss of proneural gene function may be expected to reduce or abolish $\mathrm{E}$ (spl)-C gene expression in two distinct ways (Fig. 7B): First, by the loss of direct transcriptional activation by the proneural proteins and second, by a reduction of the activity of the $\mathrm{N}$ receptor, resulting in a reduction or loss of $\mathrm{Su}(\mathrm{H})$-mediated activation as well. In contrast, mutation of the $\mathrm{E}$ box binding sites upstream of $\mathrm{E} / \mathrm{spl}$-C $\mathrm{C}$ genes would have only the first of these effects.

\section{Transcriptional activation of $E($ spl)-C genes} in response to $N$ receptor activity is inhibited by $\mathrm{H}$

We have shown here that $H$ is an effective in vivo inhibitor of the transcriptional response of $\mathrm{E}$ (spl)-C genes to hyperactivity of the $\mathrm{N}$ receptor. This finding accounts satisfactorily for our earlier observations that $H$ loss-offunction phenotypes can be suppressed by reductions in $\mathrm{E}$ (spl)-C gene dose, and that $H$ antagonizes the activity of the $\mathrm{N}$ receptor at the phenotypic level (Bang et al. 1995). We suggest that $H$ promotes stable commitment to primary (Posakony 1994) cell fates throughout adult sensory organ development by antagonizing the $\mathrm{Su}(\mathrm{H})$-mediated activation of $\mathrm{E} / \mathrm{spl})-\mathrm{C}$ genes that is induced by $\mathrm{N}$ receptor activity.

Structure of the $\mathrm{N}$ cell-cell signaling pathway in adult external sensory organ development

The positive regulatory link between $\mathrm{N}$ receptor activity, $\mathrm{Su}(\mathrm{H})$, and the transcriptional activity of the $\mathrm{E}(\mathrm{spl})-\mathrm{C}$ genes established in this study is fully consistent with previous genetic analyses of the function of these loci. The wild-type activities of all three are required to restrict the expression of particular cell fates at multiple steps of adult sensory organ development (Hartenstein and Posakony 1990; Schweisguth and Posakony 1992, 1994; Tata and Hartley 1995). For example, in the wing imaginal disc, loss of $N, \mathrm{Su}(H)$, or E(spl)-C function leads to the same phenotype-commitment of supernumerary proneural cluster cells to the SOP fate.

Incorporating the conclusions of this study, Figure 7A illustrates our current picture of the structure of the $N$ cell-cell signaling pathway as it functions in adult external sensory organ development. Each step in the pathway, as shown in the figure, represents a direct proteinprotein or protein-DNA interaction (see introductory section). The extracellular portion of the Dl ligand, presented by the "sending" cell, interacts with the extracellular domain of the $\mathrm{N}$ receptor on the "receiving" cell. When this occurs, $\mathrm{Su}(\mathrm{H})$, initially bound to the ankyrin repeats of the intracellular domain of the receptor, is activated and translocates from the cytoplasm to the nucleus. There, $\mathrm{Su}(\mathrm{H})$ acts as a direct transcriptional activator of the genes of the $\mathrm{E} / \mathrm{spl} \mid-\mathrm{C}$, leading to the elevated accumulation of a closely related set of bHLH repressor proteins, as well as the $\mathrm{E} / \mathrm{spl} / \mathrm{m} 4$ protein.

With respect to the SOP/epidermal cell fate decision in the proneural clusters, we envision that this description of the functional relationship between $\mathrm{N}, \mathrm{Su}(\mathrm{H})$, and the E(spl)-C applies to the inhibited, or non-SOP, cells. There is evidence that the SOP is likewise the recipient of $N$ pathway-mediated inhibitory signals from neighboring cells in the proneural cluster, but that it fails to respond to these signals due to the action of $\mathrm{H}$, which inhibits the DNA-binding activity of $\mathrm{Su}(\mathrm{H})$ (Fig. 7A) (Bang and Posakony 1992; Brou et al. 1994; Posakony 1994; Bang et al. 1995). Therefore, it is possible that $\mathrm{Su}(\mathrm{H})$ does not function as a transcriptional regulator in the SOP.

To understand how the $N$ pathway ultimately controls cell fate, it will be necessary to elucidate the function of the $\mathrm{E} / \mathrm{spl} / \mathrm{m} 4$ protein and identify the downstream targets of the $\mathrm{E} / \mathrm{spl} \mid-\mathrm{C}$ bHLH repressors. Down-regulation of proneural gene expression in the inhibited cells of the proneural cluster is an important feature of the SOP determination process, and it depends genetically on the activity of the E(spl)-C (Skeath and Carroll 1992). Moreover, the proximal promoter region of the proneural gene 
ac contains a high-affinity binding site for at least two E(spl)-C bHLH proteins, $\mathrm{m} 7$ and $\mathrm{m} 5$ (Ohsako et al. 1994; Van Doren et al. 1994|. Nevertheless, it remains unclear whether bHLH proteins encoded by the E(spl)-C function in vivo as direct repressors of the proneural genes (Fig. 7B).

Our demonstration that $\mathrm{Su}(\mathrm{H})$ activates $\mathrm{E}(\mathrm{spl})-\mathrm{C}$ genes directly in response to $\mathrm{N}$ receptor activity extends the known linear structure of the $N$ pathway, and further establishes that the $\mathrm{E}(\mathrm{spl})-\mathrm{C}$ is an integral member of this cell-cell signaling system. At present this architecture for the $N$ pathway is known to apply only to the development of the external sensory organs of the adult PNS of Drosophila. However, because genes homologous to $\mathrm{Dl}, \mathrm{N}, \mathrm{Su}(\mathrm{H}), \mathrm{H}$, and the $\mathrm{E}(\mathrm{spl})-\mathrm{C}$ have been identified in a variety of organisms from worms to frogs to mammals, it is likely that our findings will have more general relevance.

\section{Materials and methods}

Drosophila stocks

Flies were cultured on standard yeast-cornmeal-molasses-agar medium. The following mutations are described in Lindsley and Zimm (1992): $w^{1118}, S^{10-1}, S u(H)^{A R 9}$, and $S u(H)^{S F 8} . \mathrm{P}\left[r y^{+}\right.$, hsp70-Notch(intra)] lines 2 and 3 (Struhl et al. 1993) were provided by Gary Struhl; a P $\left[w^{+}, \mathrm{m} 8-2.61\right]$ stock (Kramatschek and Campos-Ortega 1994) was provided by José Campos-Ortega; Anne Bang supplied the $\mathrm{P}\left[\mathrm{w}^{+}, H s-H\right] 3$ line (Bang and Posakony 1992).

\section{Heat shock treatment}

Late third instar larvae were incubated in a humid chamber at $37^{\circ} \mathrm{C}$ for $2 \mathrm{hr}$ and then returned to $25^{\circ} \mathrm{C}$ for $0-3 \mathrm{hr}$ before dissection.

\section{Histology}

In situ hybridization experiments using digoxygenin-labeled antisense RNA probes were based on the protocol of Tautz and Pfeifle (1989) and performed as described in Singson et al. (1994). $\beta$-Galactosidase activity was detected as described in Romani et al. (1989). Preparations were mounted in $80 \%$ glycerol in PBS or dehydrated and mounted in Epon. Micrographs were made using Nomarski optics.

\section{Plasmid construction}

\section{$P$ element transposon constructs}

A 506-bp SacI-XhoI E(spl)m4 promoter fragment was subcloned into pBluescript $\mathrm{KS}$ ( + from an XhoI-HindIII $E(\mathrm{spl}) \mathrm{m} 4$ genomic DNA clone (Singson et al. 1994). The SacI-XhoI fragment was isolated from the subclone and treated with Klenow polymerase (Promega) to convert the termini to blunt ends; using $X b a I$ linkers (New England Biolabs), this blunt-ended fragment was cloned into the $X b a I$ site of pBluescript $\mathrm{KS}(+)$ to yield pm4XSKS. Wild-type and mutant (see below) XbaI fragments were then cloned into the $X b a I$ site of the CaSpeRLacZ $P$ element transformation vector (Margolis et al. 1994) to derive pm4CaSpeRLacZ, pm4S1,2,3mCaSpeRLacZ, and pm4E1,2mCaSpeRLacZ.

\section{$\mathrm{Su}(H)$ bacterial expression plasmid}

The oligonucleotide primers (Operon Technologies) SuH ATG (CGGAATTCTCATGAAGAGCTACAGCCAATTTAATT) and SuH TGA (CGAGCTCGTCAGGATAAGCCGCTACCATGACTA) were used in a polymerase chain reaction (PCR) to amplify a $1.8-\mathrm{kb}$ fragment from the $\mathrm{Su}(\mathrm{H}) \mathrm{cDNA}$ template pC6.12 (Schweisguth and Posakony 1992). These oligonucleotides introduce an EcoRI site $5^{\prime}$ to the $\mathrm{Su}(\mathrm{H})$ start codon and a SacI site $3^{\prime}$ to the $\mathrm{Su}(\mathrm{H})$ stop codon. The PCR product was digested with EcoRI and SacI and cloned into pBluescript KS (+ ) (Stratagene) to generate $\mathrm{pSu}(\mathrm{H})[\mathrm{ATG}-\mathrm{TGA}] \mathrm{KS}$. The nucleotide sequence of the cloned fragment was verified between the $5^{\prime} E c o R I$ site and the $N$ coI site (C6.12 position +732 ) and between the EagI site (C6.12 position +1979 ) and the 3' SacI site. The 1.8-kb EcoRISacI fragment was isolated from pSu(H)[ATG-TGA]KS and cloned into pGEX KG (Guan and Dixon 1991). Subsequently, the unverified PCR-generated NcoI-EagI restriction fragment was replaced with the corresponding fragment from pC6.12 to derive pGEXSu(H).

\section{Identification of the $\mathrm{S} 1 \mathrm{Su}(\mathrm{H})$ binding site in $\mathrm{E}(\mathrm{spl} / \mathrm{m} 8$}

During the course of this study we found a discrepancy between the previously reported sequence of the proximal upstream region of the $E$ (spl)m8 gene (Klämbt et al. 1989) and sequence that we determined independently. Our data indicate that the nucleotide at position - 185 on the antisense strand is A instead of $\mathrm{G}$. This change reveals a predicted $\mathrm{Su}(\mathrm{H})$ binding site, GTGGGAA, at position - 180 (Brou et al. 1994; Henkel et al. 1994; Tun et al. 1994). Oligonucleotide probes containing the new sequence are bound efficiently by $\mathrm{Su}(\mathrm{H})$ in vitro (see Fig. 3), whereas a probe corresponding to the originally described sequence is not (A.M. Bailey, unpubl.); see also Tun et al. (1994).

\section{Site-specific mutagenesis}

The Transformer (Clontech) site-directed mutagenesis kit was used to convert the sequence of the S1 site of pm4XSKS to GTGGCAA. Subsequently, the BamHI-PstI restriction fragment containing sites S2 and S3 was replaced with a synthetic DNA fragment in which the sequence of these sites had been changed to GTGGCAA and GTGACAA, respectively. $\mathrm{pm} 4 \mathrm{~S} 1,2,3 \mathrm{mCaSpeRlacZ}$ was derived from this intermediate as described above. The Transformer kit was used to change the sequence of both E1 and E2 ["E box" proneural protein-binding sites (Singson et al. 1994)] in pm4XSKS from CAGGTG to CCGGTT. pm4E1,2mCaSpeRlacZ was derived from this intermediate as described above. All directed changes were verified by DNA sequencing.

\section{Germ-line transformation}

The P element transformation constructs described above were coinjected with a $\Delta 2-3$ helper plasmid into the recipient strain, $w^{1118}$ (Rubin and Spradling 1982). For each construct, a minimum of 10 independent lines was established.

\section{Protein expression and purification}

The pGEXSu(H) plasmid was introduced into E. coli strain BL21 DE3. GST-Su(H) protein was expressed and purified as described in Singson et al. (1994). The protein was recovered in 25 $\mathrm{mM} \mathrm{K}^{+}$HEPES ( $\mathrm{pH} 8.0$ ), $50 \mathrm{mM} \mathrm{KCl} 5 \mathrm{~mm} \mathrm{MgCl}_{2}, 0.1 \mathrm{~mm}$ EDTA, $1 \mathrm{mM}$ DTT. Glycerol was added to $10 \%$ final concentration. The approximate protein concentration of the preparation 
was determined by comparison of Coomassie Blue staining intensity to a mass series of a protein standard (bovine serum albumin) on an SDS-polyacrylamide gel. The GST-ac and GST-da proteins were provided by Andrew Singson from the preparations described in Singson et al. (1994).

\section{Electrophoretic mobility-shift assays}

Double-stranded DNA oligonucleotide probes and specific competitors were synthesized by Operon Technologies. Each probe includes a predicted $\mathrm{Su}(\mathrm{H}$ ) binding site (Henkel et al. 1994; Tun et al. 1994) or E box site (Singson et al. 1994) identified in the proximal upstream regions of $E(s p l) m 4, E(s p l) m 8$, or $E(s p l) m \gamma$, along with adjacent sequences on either side. Oligonucleotide sequences are as follows:

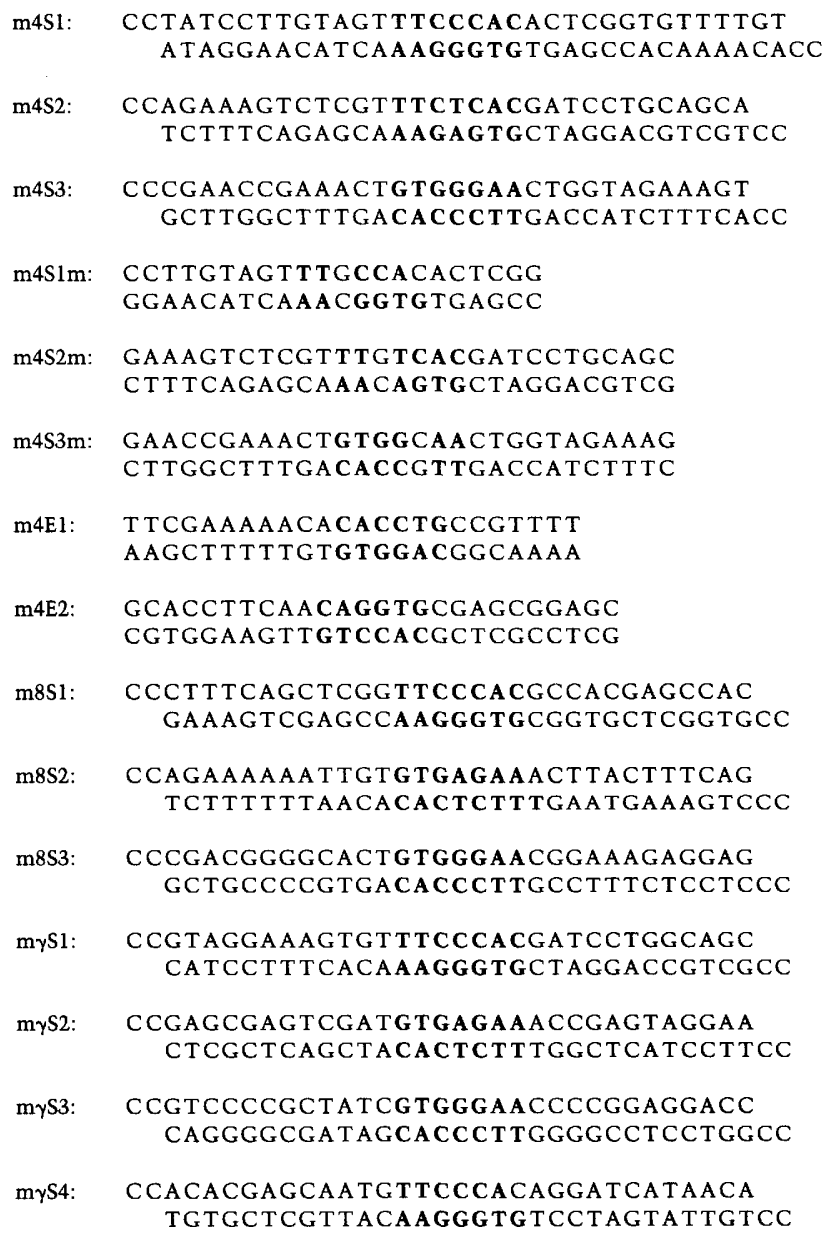

Oligonucleotides were radiolabeled by $\mathrm{T} 4$ polynucleotide kinase (Promega) and $\left[\gamma^{-}{ }^{32} \mathrm{P}\right]$ ATP. Complementary strands were annealed in the kinase reaction buffer and the double-stranded DNA probes were purified by G25-Sephadex (Sigma) chromatography. Radiolabeled probes were recovered at an estimated concentration of $25 \mathrm{nM}$ in TE buffer. Unlabeled competitor probes were prepared by annealing complementary singlestranded oligonucleotides in TE buffer. Protein-DNA mixtures were assembled at room temperature as follows: $1 \mu \mathrm{l}$ of radiolabeled probe $\left(\sim 25 \mathrm{fmoles}\right.$ at $\left.2-7 \times 10^{5} \mathrm{cpm} / \mu \mathrm{l}\right), 1 \mu \mathrm{l}$ poly[d(A-T)] $10.5 \mathrm{mg} / \mathrm{ml}$; Sigma), and $1 \mu \mathrm{l} 10 \times$ buffer $[0.1 \mathrm{M}$ Tris $-\mathrm{HCl}(\mathrm{pH}$ 7.5), $0.5 \mathrm{M} \mathrm{NaCl}, 10 \mathrm{~mm}$ DTT, $10 \mathrm{~mm}$ EDTA, $275 \mu \mathrm{g} / \mathrm{ml}$ salmon sperm DNA] were mixed. For competition assays, $0.5 \mu \mathrm{l}$ of a given competitor probe ( $1 \mu \mathrm{M}$ in TE buffer) was also included to achieve a 20 -fold molar excess over the concentration of labeled probe. Seven microliters of purified GST fusion protein was then added. For the direct binding assays of Figure $3 \mathrm{~A}$, this volume included $\sim 200 \mathrm{ng}$ of full-length $\mathrm{GST}-\mathrm{Su}(\mathrm{H})$ protein; $\sim 100 \mathrm{ng}$ was used in the competition assays (Fig. 3B). Eight microliters of the protein-DNA mixes was electrophoresed immediately on $4 \%$ polyacrylamide/ $0.5 \times$ TBE gels. Gels were fixed in $25 \%$ methanol, $7 \%$ acetic acid and dried. X-ray film (Kodak X-Omat AR) was exposed to dried gels with an intensifying screen at $-80^{\circ} \mathrm{C}$ to generate autoradiographs.

\section{Acknowledgments}

We are grateful to José Campos-Ortega and Gary Struhl for generously providing fly stocks. We greatly appreciate the assistance of Thomas Henkel and Greg Peterson at Tularik in communicating data concerning the sequence specificity of DNA binding by CBF1 before publication. We are grateful to Michael Leviten, whose results and insight motivated our initial interest in the transcriptional control of $E(\mathrm{spl}) \mathrm{m} 4$; and to Andrew Singson, for determining the sequence of the upstream region of $E$ (spl)m4, for providing preparations of proneural proteins, and for sharing fly stocks that enabled valuable control experiments. We thank Pamela Nero for constructing pSu(H)]ATGTGA]KS and Chandra Overhauser for assisting with the initial DNA-binding experiments. Valuable critical advice on the manuscript was provided by Rick Firtel, Mike Levine, and Dave Nellesen. A.M.B. received stipend support from a Powell Foundation fellowship and from a National Institutes of Health (NIH) predoctoral training grant. This work was supported by NIH grant GM46993 to J.W.P.

The publication costs of this article were defrayed in part by payment of page charges. This article must therefore be hereby marked "advertisement" in accordance with 18 USC section 1734 solely to indicate this fact.

\section{References}

Ashburner, M. 1982. The genetics of a small autosomal region of Drosophila melanogaster containing the structural gene for alcohol dehydrogenase. III. Hypomorphic and hypermorphic mutations affecting the expression of Hairless. Genetics 101: 447-459.

Bang, A.G. and J.W. Posakony. 1992. The Drosophila gene Hairless encodes a novel basic protein that controls alternative cell fates in adult sensory organ development. Genes \& Dev. 6: 1752-1769.

Bang, A.G., V. Hartenstein, and J.W. Posakony. 1991. Hairless is required for the development of adult sensory organ precursor cells in Drosophila. Development 111: 89-104.

Bang, A.G., A.M. Bailey, and J.W. Posakony. 1995. Hairless promotes stable commitment to the sensory organ precursor cell fate by negatively regulating the activity of the Notch signaling pathway. Dev. Biol. (in press).

Brou, C., F. Logeat, M. Lecourtois, J. Vandekerckhove, P. Kourilsky, F. Schweisguth, and A. Israel. 1994. Inhibition of the DNA-binding activity of Drosophila Suppressor of Hairless and of its human homolog, KBF2/RBP-JK, by direct proteinprotein interaction with Drosophila Hairless. Genes \& Dev. 8: 2491-2503. 
Cabrera, C.V. and M.C. Alonso. 1991. Transcriptional activation by heterodimers of the achaete-scute and daughterless gene products of Drosophila. EMBO F. 10: 2965-2973.

Cronmiller, C. and C. Cummings. 1993. The daughterless gene product in Drosophila is a nuclear protein that is broadly expressed throughout the organism during development. Mech. Dev. 42: 159-169.

Cubas, P., J.-F. de Celis, S. Campuzano, and J. Modolell. 1991. Proneural clusters of achaete-scute expression and the generation of sensory organs in the Drosophila imaginal wing disc. Genes \& Dev. 5: 996-1008.

de la Concha, A., U. Dietrich, D. Weigel, and J.A. CamposOrtega. 1988. Functional interactions of the neurogenic genes of Drosophila melanogaster. Genetics 118: 499-508.

Delidakis, C. and S. Artavanis-Tsakonas. 1992. The Enhancer of split [E(sp1)] locus of Drosophila encodes seven independent helix-loop-helix proteins. Proc. Natl. Acad. Sci. 89: 87318735.

Delidakis, C., A. Preiss, D.A. Hartley, and S. Artavanis-Tsakonas. 1991. Two genetically and molecularly distinct functions involved in early neurogenesis reside within the Enhancer of split locus of Drosophila melanogaster. Genetics 129: 803-823.

Dietrich, U. and J.A. Campos-Ortega. 1984. The expression of neurogenic loci in the imaginal epidermal cells of Drosophila melanogaster. J. Neurogenetics 1: 315-332.

Dou, S., X. Zeng, P. Cortes, H. Erdjument-Bromage, P. Tempst, T. Honjo, and L.D. Vales. 1994. The recombination signal sequence-binding protein RBP-2N functions as a transcriptional repressor. Mol. Cell. Biol. 14: 3310-3319.

Fehon, R.G., P.J. Kooh, I. Rebay, C.L. Regan, T. Xu, M.A. Muskavitch, and S. Artavanis-Tsakonas. 1990. Molecular interactions between the protein products of the neurogenic loci Notch and Delta, two EGF-homologous genes in Drosophila. Cell 61: 523-534.

Fortini, M.E. and S. Artavanis-Tsakonas. 1994. The Suppressor of Hairless protein participates in Notch receptor signaling. Cell 79: 273-282.

Grossman, S.R., E. Johannsen, X. Tong, R. Yalamanchili, and E. Kieff. 1994. The Epstein-Barr virus nuclear antigen 2 transactivator is directed to response elements by the Jk recombination signal binding protein. Proc. Natl. Acad. Sci. 91: 7568-7572.

Guan, K.L. and J.E. Dixon. 1991. Eukaryotic proteins expressed in Escherichia coli: An improved thrombin cleavage and purification procedure of fusion proteins with glutathione S-transferase. Anal. Biochem. 192: 262-267.

Hartenstein, V. and J.W. Posakony. 1989. Development of adult sensilla on the wing and notum of Drosophila melanogaster. Development 107: 389-405.

- 1990. A dual function of the Notch gene in Drosophila sensillum development. Dev. Biol. 142: 13-30.

Hartley, D.A., A. Preiss, and S. Artavanis-Tsakonas. 1988. A deduced gene product from the Drosophila neurogenic locus, Enhancer of split, shows homology to mammalian G-protein $\beta$ subunit. Cell 55: 785-795.

Heitzler, P. and P. Simpson. 1991. The choice of cell fate in the epidermis of Drosophila. Cell 64: 1083-1092.

Henkel, T., P.D. Ling, S.D. Hayward, and M.G. Peterson. 1994. Mediation of Epstein-Barr virus EBNA2 transactivation by recombination signal-binding protein Jк. Science 265: 9295.

Hinz, U., B. Giebel, and J.A. Campos-Ortega. 1994. The basic helix-loop-helix domain of Drosophila lethal of scute protein is sufficient for proneural function and activates neurogenic genes. Cell 76: 77-87.
Hsieh, J.J.-D. and S.D. Hayward. 1995. Masking of the CBF1/ RBPJK transcriptional repression domain by Epstein-Barr virus EBNA2. Science 268: 560-563.

Jarman, A.P., Y. Grau, L.Y. Jan, and Y.N. Jan. 1993. atonal is a proneural gene that directs chordotonal organ formation in the Drosophila peripheral nervous system. Cell 73: 13071321.

Jarman, A., E. Grell, L. Ackerman, L. Jan, and Y. Jan. 1994. atonal is the proneural gene for Drosophila photoreceptors. Nature 369: 398-400.

Jennings, B., A. Preiss, C. Delidakis, and S. Bray. 1994. The Notch signalling pathway is required for Enhancer of split bHLH protein expression during neurogenesis in the Drosophila embryo. Development 120: 3537-3548.

Klämbt, C., E. Knust, K. Tietze, and J. Campos-Ortega. 1989. Closely related transcripts encoded by the neurogenic gene complex Enhancer of split of Drosophila melanogaster. EMBO I. 8: 203-210.

Knust, E., K.A. Bremer, H. Vässin, A. Ziemer, U. Tepass, and J.A. Campos-Ortega. 1987. The Enhancer of split locus and neurogenesis in Drosophila melanogaster. Dev. Biol. 122: 262-273.

Knust, E., H. Schrons, F. Grawe, and J.A. Campos-Ortega. 1992. Seven genes of the Enhancer of split complex of Drosophila melanogaster encode helix-loop-helix proteins. Genetics 132: 505-518.

Kramatschek, B. and J.A. Campos-Ortega. 1994. Neuroectodermal transcription of the Drosophila neurogenic genes $E(s p l)$ and $H L H-m 5$ is regulated by proneural genes. Development 120: $815-826$.

Kunisch, M., M. Haenlin, and J.A. Campos-Ortega. 1994. Lateral inhibition mediated by the Drosophila neurogenic gene Delta is enhanced by proneural proteins. Proc. Natl. Acad. Sci. 91: 10139-10143.

Lieber, T., S. Kidd, E. Alcamo, V. Corbin, and M.W. Young. 1993. Antineurogenic phenotypes induced by truncated Notch proteins indicate a role in signal transduction and may point to a novel function for Notch in nuclei. Genes \& Dev. 7: 1949-1965.

Lindsley, D.L. and G.G. Zimm. 1992. The genome of Drosophila melanogaster. Academic Press, San Diego, CA.

Margolis, J.S., M. Borowsky, C.W. Shim, and J.W. Posakony. 1994. A small region surrounding the distal promoter of the hunchback gene directs maternal expression. Dev. Biol. 163: 381-388.

Meitinger, C., L.J. Strobl, G. Marschall, G.W. Bornkamm, and U. Zimber-Strobl. 1994. Crucial sequences within the Epstein-Barr virus TP1 promoter for EBNA2-mediated transactivation and interaction of EBNA2 with its responsive element. I. Virol. 68: 7497-7506.

Ohsako, S., J. Hyer, G. Pangiban, I. Oliver, and M. Caudy. 1994. hairy function as a DNA-binding helix-loop-helix repressor of Drosophila sensory organ formation. Genes \& Dev. 8: 2743-2755.

Parks, A.L. and M.A. Muskavitch. 1993. Delta function is required for bristle organ determination and morphogenesis in Drosophila. Dev. Biol. 157: 484-496.

Paroush, Z., R.L. Finley Jr., T. Kidd, S.M. Wainwright, P.W. Ingham, R. Brent, and D. Ish-Horowicz. 1994. Groucho is required for Drosophila neurogenesis, segmentation, and sex determination and interacts directly with hairy-related bHLH proteins. Cell 79: 805-815.

Posakony, J.W. 1994. Nature versus nurture: Asymmetric cell divisions in Drosophila bristle development. Cell 76: 415-418.

Romani, S., S. Campuzano, E.R. Macagno, and J. Modolell. 1989. Expression of achaete and scute genes in Drosophila imagi- 
nal discs and their function in sensory organ development. Genes \& Dev. 3: 997-1007.

Rubin, G.M. and A.C. Spradling. 1982. Genetic transformation of Drosophila with transposable element vectors. Science 218: 348-353.

Schweisguth, F. 1995. Suppressor of Hairless is required for signal reception during lateral inhibition in the Drosophila pupal notum. Development 121: 1875-1884.

Schweisguth, F. and J.W. Posakony. 1992. Suppressor of Hairless, the Drosophila homolog of the mouse recombination signal-binding protein gene, controls sensory organ cell fates. Cell 69: 1199-1212.

1994. Antagonistic activities of Suppressor of Hairless and Hairless control alternative cell fates in the Drosophila adult epidermis. Development 120: 1433-1441.

Simpson, P. 1990. Lateral inhibition and the development of the sensory bristles of the adult peripheral nervous system of Drosophila. Development 109: 509-519.

Singson, A., M.W. Leviten, A.G. Bang, X.H. Hua, and J.W. Posakony. 1994. Direct downstream targets of proneural activators in the imaginal disc include genes involved in lateral inhibitory signaling. Genes \& Dev. 8: 2058-2071.

Skeath, J.B. and S.B. Carroll. 1991. Regulation of achaete-scute gene expression and sensory organ pattern formation in the Drosophila wing. Genes \& Dev. 5: 984-995.

- 1992. Regulation of proneural gene expression and cell fate during neuroblast segregation in the Drosophila embryo. Development 114: 939-946.

Struhl, G., K. Fitzgerald, and I. Greenwald. 1993. Intrinsic activity of the Lin-12 and Notch intracellular domains in vivo. Cell 74: 331-345.

Takebayashi, K., Y. Sasai, Y. Sakai, T. Watanabe, S. Nakanishi, and R. Kageyama. 1994. Structure, chromosomal locus, and promoter analysis of the gene encoding the mouse helixloop-helix factor HES-1. Negative autoregulation through the multiple $\mathrm{N}$ box elements. I. Biol. Chem. 269:51505156.

Tata, F. and D.A. Hartley. 1995. Inhibition of cell fate in Drosophila by Enhancer of split genes. Mech. Dev. 51: 305-315.

Tautz, D. and C. Pfeifle. 1989. A non-radioactive in situ hybridization method for the localization of specific RNAs in Drosophila embryos reveals translational control of the seg. mentation gene hunchback. Chromosoma 98: 81-85.

Tietze, K., N. Oellers, and E. Knust. 1992. Enhancer of split ${ }^{D}$, a dominant mutation of Drosophila, and its use in the study of functional domains of a helix-loop-helix protein. Proc. Natl. Acad. Sci. 89: 6152-6156.

Tun, T., Y. Hamaguchi, N. Matsunami, T. Furukawa, T. Honjo, and M. Kawaichi. 1994. Recognition sequence of a highly conserved DNA binding protein RBP-Jк. Nucleic Acids Res. 22: 965-971.

Van Doren, M., H.M. Ellis, and J.W. Posakony. 1991. The Drosophila extramacrochaetae protein antagonizes sequencespecific DNA binding by daughterless/achaete-scute protein complexes. Development 113: 245-255.

Van Doren, M., P.A. Powell, D. Pasternak, A. Singson, and J.W. Posakony. 1992. Spatial regulation of proneural gene activity: Auto- and cross-activation of achaete is antagonized by extramacrochaetae. Genes \& Dev. 6: 2592-2605.

Van Doren, M., A. Bailey, J. Esnayra, K. Ede, and J. Posakony. 1994. Negative regulation of proneural gene activity: hairy is a direct transcriptional repressor of achaete. Genes \& Dev. 8: 2729-2742.

Vässin, H., J. Vielmetter, and J.A. Campos-Ortega. 1985. Genetic interactions in early neurogenesis of Drosophila melanogaster. J. Neurogenetics 2: 291-308.
Waltzer, L., F. Logeat, C. Brou, A. Israel, A. Sergeant, and E. Manet. 1994. The human JK recombination signal sequence binding protein (RBP-JK) targets the Epstein-Barr virus EBNA2 protein to its DNA responsive elements. EMBO $\%$. 13: $5633-5638$. 


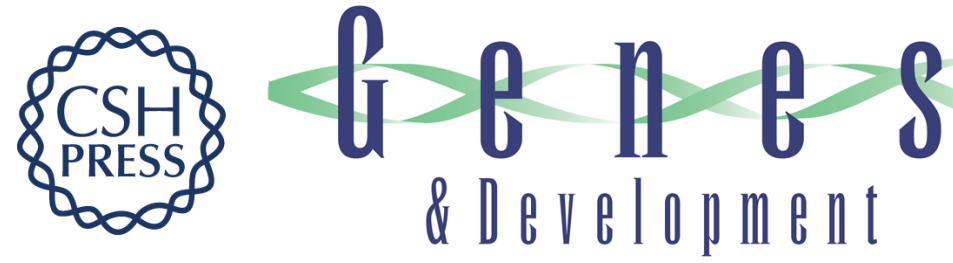

\section{Suppressor of hairless directly activates transcription of enhancer of split complex genes in response to Notch receptor activity.}

A M Bailey and J W Posakony

Genes Dev. 1995, 9:

Access the most recent version at doi:10.1101/gad.9.21.2609

References This article cites 58 articles, 33 of which can be accessed free at:

http://genesdev.cshlp.org/content/9/21/2609.full.html\#ref-list-1

License

Email Alerting

Service

Receive free email alerts when new articles cite this article - sign up in the box at the top right corner of the article or click here.

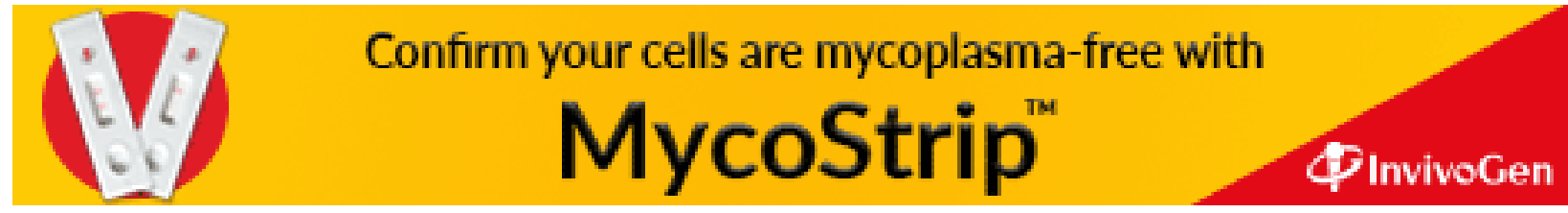

